OPEN ACCESS

Edited by:

Robson G. Santos,

Federal University of Alagoas, Brazil

Reviewed by:

Leandro Bugoni,

Federal University of Rio Grande,

Brazil

Qamar Schuyler,

Oceans and Atmosphere (CSIRO),

Australia

*Correspondence:

Victoria González Carman vgcarman@inidep.edu.ar

Specialty section:

This article was submitted to

Marine Pollution,

a section of the journal

Frontiers in Marine Science

Received: 22 April 2021

Accepted: 11 August 2021

Published: 16 September 2021

Citation:

González Carman V, Denuncio P, Vassallo M, Berón MP, Álvarez KC

and Rodriguez-Heredia S (2021)

Charismatic Species as Indicators of Plastic Pollution in the Río de la

Plata Estuarine Area, SW Atlantic.

Front. Mar. Sci. 8:699100.

doi: 10.3389/fmars.2021.699100

\section{Charismatic Species as Indicators of Plastic Pollution in the Río de la Plata Estuarine Area, SW Atlantic}

\author{
Victoria González Carman ${ }^{1,2 *}$, Pablo Denuncio ${ }^{1,3}$, Martina Vassallo4, María Paula Berón1, \\ Karina C. Álvarez ${ }^{5}$ and Sergio Rodriguez-Heredia ${ }^{5}$
}

${ }^{1}$ Instituto de Investigaciones Marinas y Costeras (IIMYC, UNMdP-CONICET), Mar del Plata, Argentina, ${ }^{2}$ Instituto Nacional de Investigación y Desarrollo Pesquero, Mar del Plata, Argentina, ${ }^{3}$ Asociación Naturalistas Geselinos, Villa Gesell, Argentina, ${ }^{4}$ Universidad Nacional de Mar del Plata, Mar del Plata, Argentina, ${ }^{5}$ Fundación Mundo Marino, San Clemente del Tuyú, Argentina

Marine plastic pollution is projected to increase globally in the next few decades. This holds true for South America where the number of species that interacts with plastics is increasing. In this study, we explore for the first time the potential of certain charismatic species of marine turtles, mammals and seabirds as indicators of plastic pollution in the Río de la Plata (RdP), one of the largest and most important estuarine areas of the Southwest Atlantic. Through a revision of published studies integrated with unpublished data, we summarize studies on the interaction of charismatic marine species with plastics in the region and evaluate their role as indicators of plastic pollution in the RdP based on aspects of their local ecology and key attributes (i.e., biological/ecological, methodological, and conservation attributes) of indicator species. We found that at least 45 charismatic marine species interact -whether by ingestion or entanglement- with plastics in the region. Eight of these species were selected as potential indicators given their occurrence, probability of sampling and interaction with plastics in the RdP, namely: Chelonia mydas, Caretta caretta, Dermochelys coriacea, Pontoporia blainvillei, Arctocephalus australis, Otaria flavescens, Larus dominicanus, and Spheniscus magellanicus. The species shared some key attributes of indicator species, e.g., they are relatively well studied, but differed in critical aspects such as their home range and mobility. We discuss whether the species' attributes are strengths or weaknesses according to the available knowledge on their ecology in the RdP, and propose a multispecies indicator of plastic pollution given that those strengths and weaknesses can be compensated among species. Monitoring plastic pollution through a combination of species would enable a better understanding of plastic pollution in this relevant area.

Keywords: ecosystem health, endangered species, marine debris, marine mammals, seabirds, marine turtles, South America 


\section{INTRODUCTION}

The generation and disposal of plastic waste is projected to increase dramatically worldwide in the next decades (Geyer et al., 2017; Lebreton and Andrady, 2019; Borrelle et al., 2020). In South America, this trend is led by urban centers in Brazil and Argentina. A considerable proportion of this waste will reach the marine environment due to the proximity of urban centers to coastal or riverine areas (Leite et al., 2014; Jambeck et al., 2018; Andrades et al., 2020), with the consequent effects on the ecosystems. Numerous studies document for the interaction of several marine species with plastic in the region (e.g., Tourinho et al., 2010; Santos et al., 2011; Petry and Benemann, 2017). However, the awareness raised by this growing field of research has not yet been translated into regional management strategies such as pollution reduction or ecological quality goals (e.g., Avery-Gomm et al., 2018). In this study, we center our attention on the Río de la Plata (RdP), one of the largest and most important estuarine areas of South America (Mianzan et al., 2001).

The RdP estuarine area holds a highly productive frontal system sustaining extensive benthic habitats and high plankton and fish biomass (Mianzan et al., 2001; Acha et al., 2008). It is subject to strong anthropogenic pressure due to the development of artisanal and industrial fisheries and the presence of major metropolitan and industrialized areas along the coasts of Argentina and Uruguay. It is the maritime access to the "Hidrovia," a fluvial waterway system for commerce with intense vessel traffic (Defeo et al., 2011; Elías et al., 2011; Lozoya et al., 2015). It is also an important foraging ground for several charismatic species of marine turtles, dolphins, pinnipeds, and seabirds (Bordino et al., 2008; González Carman et al., 2016a), which are regularly found stranded on beaches due to bycatch, pollution, or unknown causes (González Carman et al., 2011; Vélez-Rubio et al., 2013; Stokes et al., 2014). Some studies have reported the interaction - whether by ingestion or entanglement - of these species with plastic debris in the RdP (e.g., Denuncio et al., 2011, 2017a; González Carman et al., 2014a), but an integral assessment of plastic pollution in this relevant estuarine area is lacking.

In the RdP and its main tributaries, plastic pollution has been studied through water and sediment samples (Acha et al., 2003; Blettler et al., 2017, 2019; Pazos et al., 2018). These approaches, however, have their limitations. Water sampling is logistically difficult and expensive in the RdP because it requires large research vessels for sampling along its vast extent. Sediment samples -though relatively easier to collectare limited to those plastics stranded ashore, thus are not very representative of the entire plastic load of the system. A complementary approach to study plastic pollution in the RdP could be that of focal species, especially indicator species. Broadly, indicator species are those living organisms that provide information on the state of a system and its changes (Bartell, 2006; Heink and Kowarik, 2010). In the case of condition indicator species, their occurrence, abundance, or health condition reflect changes in the quality of the environment (Zacharias and Roff, 2001; Bonanno and Orlando-Bonaca, 2018).
Nearly $50 \%$ of the taxa used as indicators are animals, $70 \%$ of which are invertebrates. Species are usually selected as indicators due to their local abundance, ecological significance, critical conservation status, or charisma (Siddig et al., 2016). Charismatic species, though controversial in its definition and scientific rigor, have an unquestionable importance in biodiversity conservation (Ducarme et al., 2013). Among the most charismatic species in the world are those belonging to the marine megafauna, i.e., large, widespread and easily observable organisms that display a set of traits appreciated by humans (Albert et al., 2018). Charismatic species of marine turtles, mammals and seabirds have long been considered sentinels of marine ecosystem health (Aguirre and Lutz, 2004; Burger and Gochfeld, 2004; Wells et al., 2004), but only recently they have been used as indicators of plastic pollution (van Franeker et al., 2011; Campani et al., 2014; Bonanno and Orlando-Bonaca, 2018).

In this study, we evaluate the potential of certain charismatic species of marine turtles, mammals, and seabirds as indicators of plastic pollution in the RdP. Through a revision of published studies integrated with unpublished data, we aim to: (1) establish key attributes of indicator species of plastic pollution, (2) summarize studies on the interaction of charismatic marine species with plastics in the region, and (3) select some of these species as potential indicators of plastic pollution in the RdP. We discuss if the species' attributes are strengths or weaknesses according to the available knowledge on their ecology in the RdP, and propose a multispecies indicator of plastic pollution given that weak and strong attributes can compensate among species.

\section{MATERIALS AND METHODS}

\section{Study Area and Management Context}

The RdP estuarine area is located within the Warm Temperate Southwest Atlantic (WTSA) province that includes the Southeastern Brazil (I), Rio Grande (II), Uruguay-Buenos Aires Shelf (III), and Río de la Plata (IV) ecoregions (Figure 1; Spalding et al., 2007). Although the RdP itself (IV) extends from the confluence of the Paraná and Uruguay rivers (Punta Gorda: $\left.33^{\circ} 54^{\prime} 58^{\prime \prime} \mathrm{S}, 58^{\circ} 24^{\prime} 52^{\prime \prime} \mathrm{W}\right)$ to the imaginary line connecting Punta Rasa (Argentina) and Punta del Este (Uruguay) (Mianzan et al., 2001; FREPLATA, 2021), the influence of its estuarine waters (known as the Plata plume) extends north (up to $\sim 25^{\circ} \mathrm{S}$, ecoregion I) in austral winter (Piola et al., 2008). Therefore, for the purpose of this study, we defined the RdP estuarine area as the waters within ecoregion IV and adjacent waters within ecoregion III (Figure 1). This is in coincidence with the action area of the main management instrument of the region: the Rio de la Plata Bilateral Treaty.

The Rio de la Plata Bilateral Treaty signed by Argentina and Uruguay develops guidelines regarding some social, economic, and political issues. In particular, the treaty aims to prevent pollution of the RdP by banning the dumping of hydrocarbons and special attention is given to land-based pollution originating from municipal sewage, tannery, and agricultural activities (FREPLATA, 2021). Major inputs of 

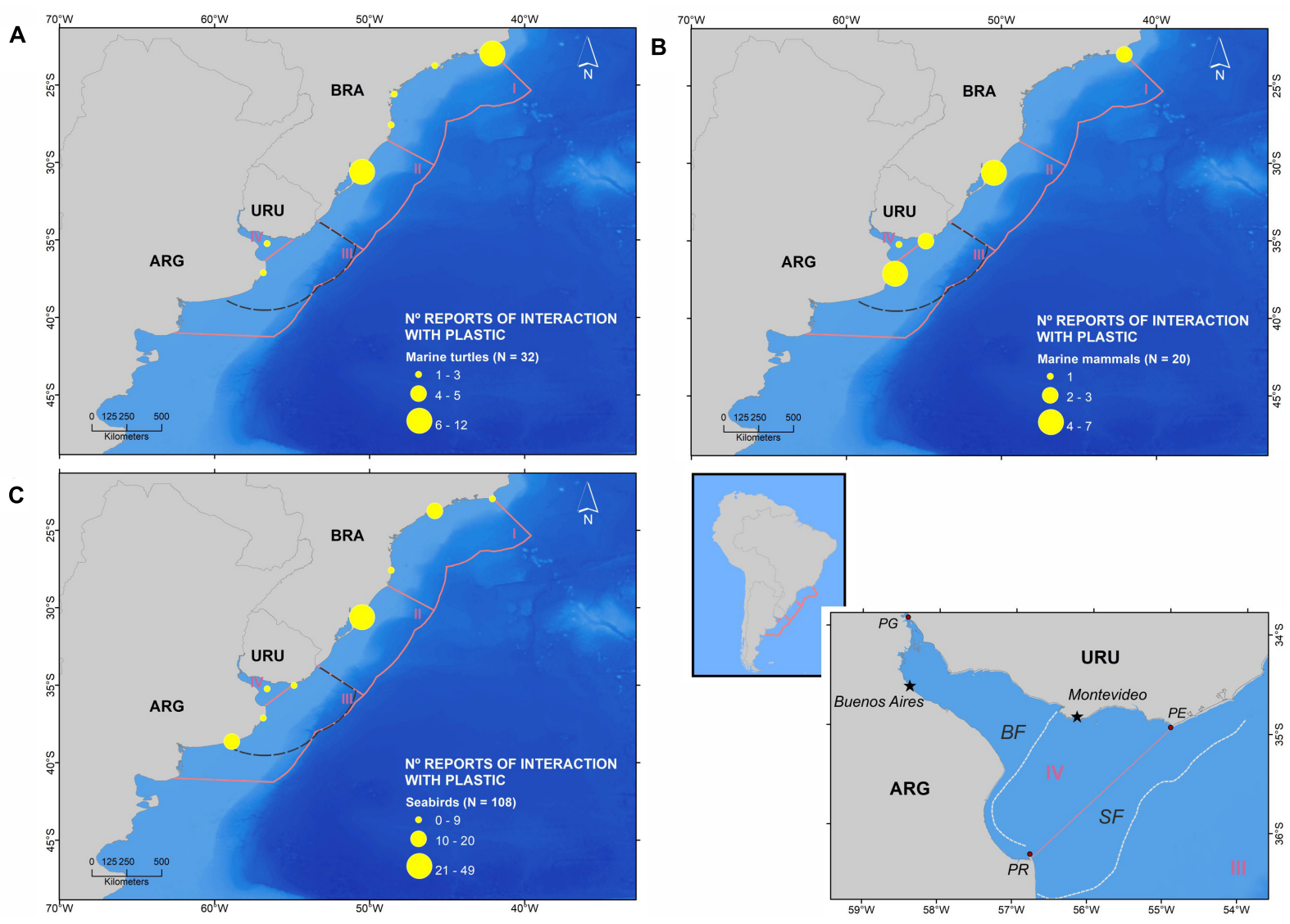

FIGURE 1 | Distribution of reports on the interaction of charismatic species of (A) marine turtles, (B) mammals, and (C) seabirds with plastics in the Warm Temperate Southwest Atlantic. Ecoregions within the study area are denoted with pink line and numbers: I, Southeastern Brazil; II, Rio Grande; III, Uruguay-Buenos Aires Shelf; and IV, Río de la Plata. Gray dashed line indicates the area of action of the Río de la Plata Bilateral Treaty. White-dashed lines denote the Río de la Plata bottom (BF) and surface (SF) frontal system. BRA, Brazil; URU, Uruguay; ARG, Argentina; PG, Punta Gorda; PR, Punta Rasa; PE, Punta del Este.

plastic come from industrial and urban areas lying along its coastline. In cities such as Buenos Aires and Montevideo waste management is limited to household collection, public cleansing, and landfilling. Plastic waste originating from these major urban areas reaches the RdP via streams and municipal drainage systems. Additional sources are via beach pollution and wind that blows waste from overfilled landfills. Intense vessel traffic and fishing also increase the plastic load to the area (González Carman et al., 2015; Lozoya et al., 2015).

In the RdP, plastics accumulate in a frontal system that is the result of the confluence of riverine and estuarine waters (Figure 1; Acha et al., 2003). In this frontal system, freshwater flows seaward on the surface, and denser, saline shelf water intrudes along the bottom, generating two salinity fronts: a bottom and a surface front at the inner and outer part of the estuary, respectively. They are separated by $c a .150 \mathrm{~km}$ and are connected by a salt-wedge (Mianzan et al., 2001).

\section{Indicator Species of Plastic Pollution}

To establish the key attributes of indicator species of plastic pollution, we reviewed the literature on focal species in conservation. We searched Scopus and Google Scholar for the terms indicator, bioindicator, indicator species, focal species, pollution, plastic, plastic pollution, marine debris, sentinel species, sentinels, marine ecosystem health, and conservation. These were paired with marine mammal, marine turtle, sea turtle, and seabird. In addition, all cited references from each study we reviewed were extensively searched for keywords described above.

We screened the literature to focus on condition indicator species only. Condition indicator species are those useful for measuring environmental changes in a habitat, community or ecosystem due to anthropogenic or natural disturbances (Zacharias and Roff, 2001). This term is used analogously to the terms bioindicators, sentinel, and health indicator species by several authors (e.g., Caro and O’Doherty, 1999; Bartell, 2006; Sergio et al., 2008; Durant et al., 2009). We then analyzed articles describing key attributes of indicator species (e.g., Hilty and Merenlender, 2000, Burger and Gochfeld, 2004; Miller et al., 2014) and listed those attributes (Table 1) that make sense for plastic pollution based on case studies on marine turtles, mammals, and seabirds (e.g., Ryan, 1987; 
TABLE 1 | Biological/ecological, methodological, and conservation attributes of good indicator species of plastic pollution.

\begin{tabular}{|c|c|c|}
\hline Attributes & Detail & References \\
\hline \multicolumn{3}{|l|}{ Biological/ecological } \\
\hline Abundance & Local abundance of the species or populations to allow long-term monitoring & $\begin{array}{l}\text { Burger and Gochfeld, 2004; Miller et al., } \\
2014\end{array}$ \\
\hline Distribution & Wide geographic distribution of the species to allow comparisons between different locations & Caro and O’Doherty, 1999; Caro, 2010 \\
\hline $\begin{array}{l}\text { Home range (core } \\
\text { area) }\end{array}$ & $\begin{array}{l}\text { Small to medium home range - or well-known core area- of the population to provide local } \\
\text { information on pollution levels }\end{array}$ & $\begin{array}{l}\text { Caro and O'Doherty, 1999; van Franeker } \\
\text { et al., } 2011\end{array}$ \\
\hline Mobility & $\begin{array}{l}\text { Low mobility of individuals to reduce the probability of avoidance of local disturbances through } \\
\text { movement or migration, and to assure local information on pollution levels }\end{array}$ & Caro, 2010; Hilty and Merenlender, 2000 \\
\hline Feeding habits & $\begin{array}{l}\text { Particular feeding habits of individuals -e.g., benthic, pelagic- may affect the probability of plastic } \\
\text { ingestion (e.g., pelagic feeding marine turtles are more likely to ingest soft plastic than benthic ones) }\end{array}$ & $\begin{array}{l}\text { Schuyler Q. et al., 2014; Roman et al., } \\
\text { 2016; Tavares et al., } 2017\end{array}$ \\
\hline Diet & $\begin{array}{l}\text { Certain diets may affect the probability of individuals to ingest some types and amount of plastics } \\
\text { (e.g., carnivorous marine turtles appear to be less likely to ingest plastics than other species) }\end{array}$ & $\begin{array}{l}\text { Ryan, 1987; Schuyler Q. et al., 2014; } \\
\text { Roman et al., 2019a }\end{array}$ \\
\hline \multicolumn{3}{|l|}{ Methodological } \\
\hline Taxonomy & Stable and well-described taxonomy to define the species reliably & $\begin{array}{l}\text { Hilty and Merenlender, 2000; Becker } \\
\text { et al., } 2003\end{array}$ \\
\hline State of knowledge & $\begin{array}{l}\text { Detailed knowledge on key ecological aspects (e.g., distribution, migration habits, and feeding } \\
\text { behavior) of the species and the sampled population to better interpret results }\end{array}$ & $\begin{array}{l}\text { Caro and O'Doherty, 1999; Furness and } \\
\text { Camphuysen, 1997; Hazen et al., } 2019\end{array}$ \\
\hline $\begin{array}{l}\text { Background } \\
\text { information }\end{array}$ & Previously published data for the species on ingestion or entanglement in plastic & Fossi et al., 2018 \\
\hline Lethality & $\begin{array}{l}\text { Known lethality or tolerance levels of the species to plastic ingestion and entanglement to detect } \\
\text { measurable changes as a result of small or medium impacts }\end{array}$ & $\begin{array}{l}\text { Hilty and Merenlender, 2000; Bonanno } \\
\text { and Orlando-Bonaca, } 2018\end{array}$ \\
\hline Retention time & $\begin{array}{l}\text { Understanding the retention time of plastics in the digestive tract of the species to interpret plastic } \\
\text { pollution at the appropriate spatial-scale resolution }\end{array}$ & $\begin{array}{l}\text { Camedda et al., 2014; van Franeker and } \\
\text { Law, } 2015\end{array}$ \\
\hline Sampling & $\begin{array}{l}\text { Conspicuous species and pre-existence of sampling networks may facilitate the identification of } \\
\text { individuals and reduce monitoring costs }\end{array}$ & $\begin{array}{l}\text { Caro and O'Doherty, 1999; Hazen et al., } \\
\text { 2019; Bonanno and Orlando-Bonaca, } \\
2018\end{array}$ \\
\hline \multicolumn{3}{|l|}{ Conservation } \\
\hline Public profile & High-profile species of public interest to raise awareness about plastic pollution & $\begin{array}{l}\text { Burger and Gochfeld, 2004; Aguirre and } \\
\text { Lutz, } 2004\end{array}$ \\
\hline Conservation status & $\begin{array}{l}\text { Threatened or endangered species to help understand how marine litter can affect the conservation } \\
\text { status of the species }\end{array}$ & $\begin{array}{l}\text { Fossi et al., } 2018 \text { (but see Hilty and } \\
\text { Merenlender, 2000) }\end{array}$ \\
\hline
\end{tabular}

van Franeker et al., 2011; Schuyler Q. et al., 2014; Bonanno and Orlando-Bonaca, 2018).

To summarize studies on the interaction of charismatic marine species with plastics in the WTSA, we searched Scopus and Google Scholar for the terms plastic, plastic pollution, marine debris paired with marine mammal, marine turtle, sea turtle, seabird and Brazil, Uruguay, and Argentina. As before, studies found were screened for additional references. We considered studies of marine turtles, mammals, and seabirds distributed in the WTSA that have included at least one report of interaction (whether by ingestion or entanglement) with plastics $\geq 2 \mathrm{~mm}$ (mostly macro, meso, and the largest size of microplastics; Cole et al., 2011). Since some studies reported interaction with plastics for more than one taxa, we concentrated on quantifying the reports of interactions per species (omitting studies that report interaction on the same individual animals). For each report, we summarized data on location, type of interaction, number of samples (i.e., individuals, digestive tracts, and seabird pellets), percentage of positive samples (i.e., samples with at least one piece of plastic from the total number of samples), type of plastic and plastic origin (Table 2 and Supplementary Table 1). We included studies on animals entangled in domestic plastics such as packaging or plastic bags, and animals entangled in abandoned, lost, or otherwise discarded fishing gear (shorten to ALDFG). We excluded those studies reporting animals that clearly got entangled in active fishing gear. Unpublished data on plastic ingestion or entanglement were also included.

In the studies reviewed, the type of plastic involved in the interaction was reported in various ways (e.g., plastic bags, packaging, film-like plastic, laminar plastic, hard fragments, rigid plastic, pieces of plastic, etc.), so we reclassified and standardized them according to the categories proposed by Provencher et al. (2017). Plastics were considered as: industrial plastic pellets (IND) and user plastics (USE, subcategories: she, sheetlike plastics; thr, threadlike plastics; foa, foamed plastics; fra, fragments; and oth, other). Because some studies grouped plastics under the category "marine debris" (that also includes wood, metal, paper, glass, rubber, and cloth debris), we separated plastics from the rest of debris when possible.

According to the percentage of positive samples reported in each study, we defined a rate of incidence for interaction with plastics as: "VERY HIGH" (100-80.0\%), "HIGH" (79.9-60.0\%), "MEDIUM" (59.9-40.0\%), "LOW” (39.9-20.0\%), "VERY LOW" (19.9-0.1\%), and "NULL" (equal to 0 ). We did not calculate a rate of incidence for studies with less than 15 samples, or those studies not reporting the total number of samples examined (e.g., most studies reporting entanglement). In fact, the rate of incidence of entanglement was only calculated for the unpublished data 
TABLE 2 | Species that interact with plastics in the Warm Temperate Southwest Atlantic and their occurrence in the Río de la Plata estuarine area.

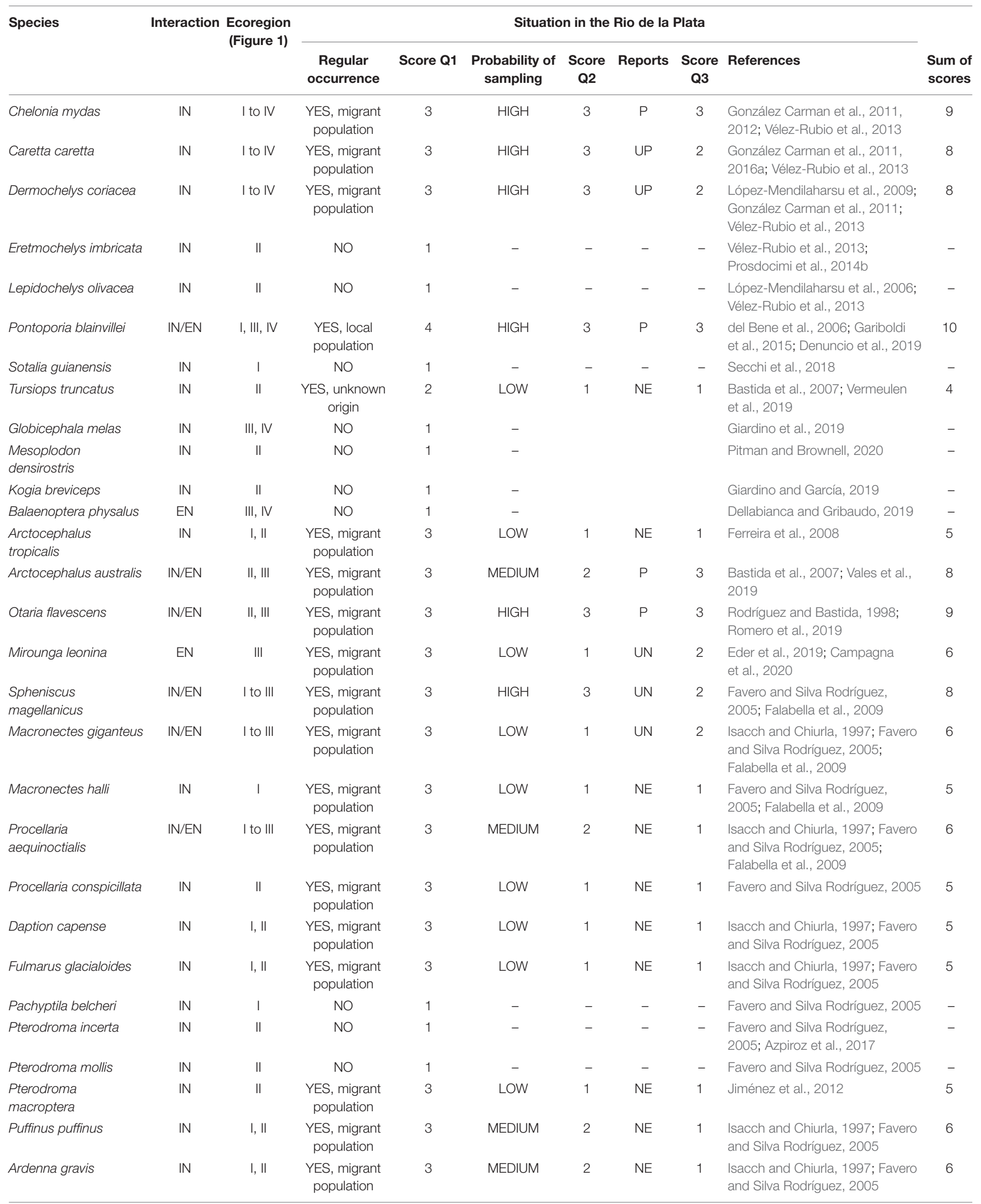


TABLE 2 | (Continued)

\begin{tabular}{|c|c|c|c|c|c|c|c|c|c|c|}
\hline \multirow[t]{2}{*}{ Species } & \multirow[t]{2}{*}{ Interaction } & \multirow{2}{*}{$\begin{array}{l}\text { Ecoregion } \\
\text { (Figure 1) }\end{array}$} & \multicolumn{7}{|c|}{ Situation in the Rio de la Plata } & \multirow[b]{2}{*}{$\begin{array}{l}\text { Sum of } \\
\text { scores }\end{array}$} \\
\hline & & & $\begin{array}{c}\text { Regular } \\
\text { occurrence }\end{array}$ & Score Q1 & $\begin{array}{l}\text { Probability of } \\
\text { sampling }\end{array}$ & $\begin{array}{c}\text { Score } \\
\text { Q2 }\end{array}$ & Reports & $\begin{array}{c}\text { Score } \\
\text { Q3 }\end{array}$ & References & \\
\hline Ardenna grisea & IN/EN & | to ||| & $\begin{array}{l}\text { YES, migrant } \\
\text { population }\end{array}$ & 3 & LOW & 1 & NE & 1 & $\begin{array}{l}\text { Isacch and Chiurla, 1997; Favero } \\
\text { and Silva Rodríguez, } 2005\end{array}$ & 5 \\
\hline Calonectris borealis & IN & $\|$ & $\begin{array}{l}\text { YES, migrant } \\
\text { population }\end{array}$ & 3 & LOW & 1 & $\mathrm{NE}$ & 1 & Favero and Silva Rodríguez, 2005 & 5 \\
\hline Calonectris edwardsii & IN & $\|$ & $\begin{array}{l}\text { YES, migrant } \\
\text { population }\end{array}$ & 3 & LOW & 1 & $\mathrm{NE}$ & 1 & $\begin{array}{l}\text { González-Solís et al., 2009; } \\
\text { BirdLife International, 2018a }\end{array}$ & 5 \\
\hline $\begin{array}{l}\text { Thalassarche } \\
\text { melanophris }\end{array}$ & IN/EN & | to ||| & $\begin{array}{l}\text { YES, migrant } \\
\text { population }\end{array}$ & 3 & LOW & 1 & UP & 3 & $\begin{array}{l}\text { Isacch and Chiurla, 1997; Favero } \\
\text { and Silva Rodríguez, 2005; } \\
\text { Falabella et al., 2009; Copello } \\
\text { et al., } 2013\end{array}$ & 7 \\
\hline $\begin{array}{l}\text { Thalassarche } \\
\text { chlororhynchos }\end{array}$ & IN/EN & | to ||| & $\begin{array}{l}\text { YES, migrant } \\
\text { population }\end{array}$ & 3 & MEDIUM & 2 & $\mathrm{NE}$ & 1 & $\begin{array}{l}\text { Isacch and Chiurla, 1997; Favero } \\
\text { and Silva Rodríguez, } 2005 \text {; } \\
\text { Azpiroz et al., } 2017\end{array}$ & 6 \\
\hline Diomedea dabbenena & IN & III & $\mathrm{NO}$ & 1 & - & - & - & & Favero and Silva Rodríguez, 2005 & - \\
\hline Diomedea sanfordi & IN & III & $\mathrm{NO}$ & 1 & - & - & - & & $\begin{array}{l}\text { Favero and Silva Rodríguez, } \\
\text { 2005; Falabella et al., 2009; } \\
\text { Azpiroz et al., } 2017\end{array}$ & - \\
\hline Diomedea epomophora & IN & II, III & $\mathrm{NO}$ & 1 & - & - & - & & Favero and Silva Rodríguez, 2005 & - \\
\hline $\begin{array}{l}\text { Chroicocephalus } \\
\text { maculipennis }\end{array}$ & EN & III & $\begin{array}{l}\text { YES, local } \\
\text { population }\end{array}$ & 4 & LOW & 1 & $\mathrm{NE}$ & 1 & $\begin{array}{l}\text { Silva Rodríguez et al., 2005; } \\
\text { Azpiroz et al., } 2017\end{array}$ & 6 \\
\hline Larus dominicanus & IN/EN & III, IV & $\begin{array}{l}\text { YES, local } \\
\text { population }\end{array}$ & 4 & MEDIUM & 2 & $\mathrm{P}$ & 3 & $\begin{array}{l}\text { Silva Rodríguez et al., 2005; } \\
\text { Favero et al., } 2016\end{array}$ & 9 \\
\hline Larus atlanticus & IN/EN & III, IV & $\begin{array}{l}\text { YES, migrant } \\
\text { population }\end{array}$ & 3 & MEDIUM & 2 & $\mathrm{NE}$ & 1 & $\begin{array}{l}\text { Silva Rodríguez et al., 2005; } \\
\text { Favero et al., 2016; Azpiroz et al., } \\
2017\end{array}$ & 6 \\
\hline Sterna hirundinacea & EN & III & $\begin{array}{l}\text { YES, migrant } \\
\text { population }\end{array}$ & 3 & LOW & 1 & $\mathrm{NE}$ & 1 & $\begin{array}{l}\text { Silva Rodríguez et al., 2005; } \\
\text { Favero et al., } 2016\end{array}$ & 5 \\
\hline Sterna hirundo & IN & I & $\begin{array}{l}\text { YES, migrant } \\
\text { population }\end{array}$ & 3 & LOW & 1 & $\mathrm{NE}$ & 1 & $\begin{array}{l}\text { Silva Rodríguez et al., 2005; } \\
\text { Favero et al., } 2016\end{array}$ & 5 \\
\hline Chionis albus & EN & III & NO & 3 & LOW & 1 & $\mathrm{NE}$ & 1 & BirdLife International, 2017 & 5 \\
\hline Haematopus palliatus & IN & I & $\begin{array}{l}\text { YES, local } \\
\text { population }\end{array}$ & 4 & LOW & 1 & $\mathrm{NE}$ & 1 & Favero et al., 2016 & 6 \\
\hline Rynchops niger & IN & $\|$ & $\begin{array}{l}\text { YES, migrant } \\
\text { population }\end{array}$ & 3 & MEDIUM & 2 & $\mathrm{NE}$ & 1 & Silva Rodríguez et al., 2005 & 6 \\
\hline Podicephorus major & IN/EN & III & $\begin{array}{l}\text { YES, local } \\
\text { population }\end{array}$ & 4 & LOW & 1 & UP & 2 & Favero et al., 2016 & 7 \\
\hline $\begin{array}{l}\text { Nannopterum } \\
\text { brasilianus }\end{array}$ & EN & III & $\begin{array}{l}\text { YES, local } \\
\text { population }\end{array}$ & 4 & LOW & 1 & UP & 2 & Favero et al., 2016 & 7 \\
\hline
\end{tabular}

Ecoregions are: I, Southeastern Brazil; II, Rio Grande; III, Uruguay-Buenos Aires Shelf; IV, Río de la Plata.

IN, ingestion; EN, Entanglement; NC, not calculated; NR, not reported.

included in this study, which were obtained through systematic surveys in which sampling effort was relatively constant. In this case, the rate of incidence of entanglement was calculated as the number of entangled individuals divided by the total number of individuals observed (Supplementary Table 1). Origin of plastic was classified as urban (URB, plastics from urban centers reaching the marine environment through run-off, beach tourism or disposed from vessels) and fishing activities (FISH, plastic remains of fishing gear used by artisanal, recreational and industrial fisheries).

To select charismatic species as indicators we followed a threequestion structured scheme that scored species according to their occurrence, probability of sampling and interaction with plastics in the RdP (Figure 2). Starting from all the species reported to interact with plastic in the ecoregions of the WTSA (Table 2), we defined and scored their occurrence in the RdP as: "NO" (no occurrence $=1$ ), "YES, unknown origin" (the species occurs in the RdP but it is unknown whether is a local or migrant population $=2$ ), "YES, migrant population" (the species occurs seasonally in the RdP = 3) and "YES, local population" (the species occurs year-round in the $\mathrm{RdP}=4$ ). We then defined the probability of sampling the species in the RdP given their chance of being found at beaches (e.g., through stranding monitoring), port facilities (e.g., recovery of bycaught individuals, observation of live individuals while resting or feeding) and at reproductive colonies or roosting 


\section{QUESTIONS}

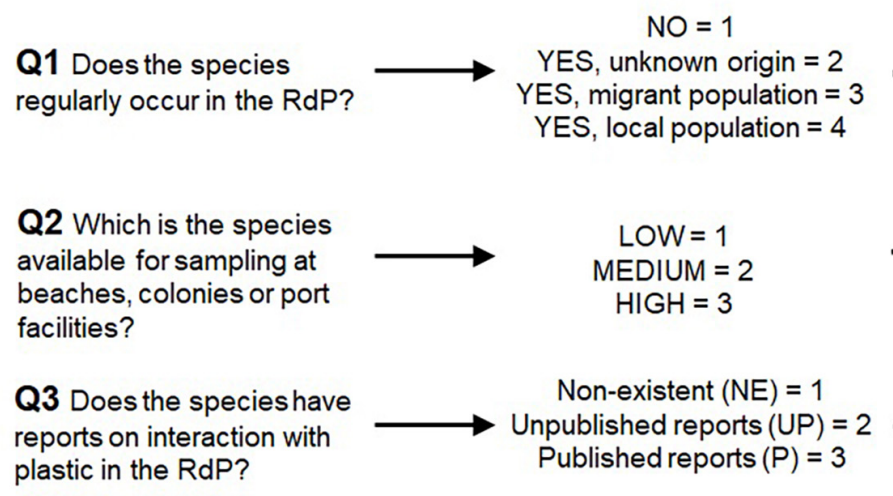

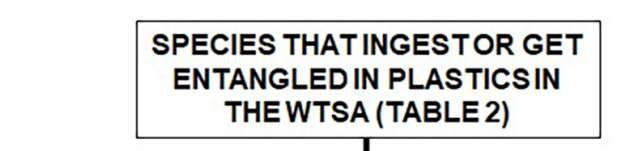

SPECIES THATINGESTOR GET

THE WTSA (TABLE 2)
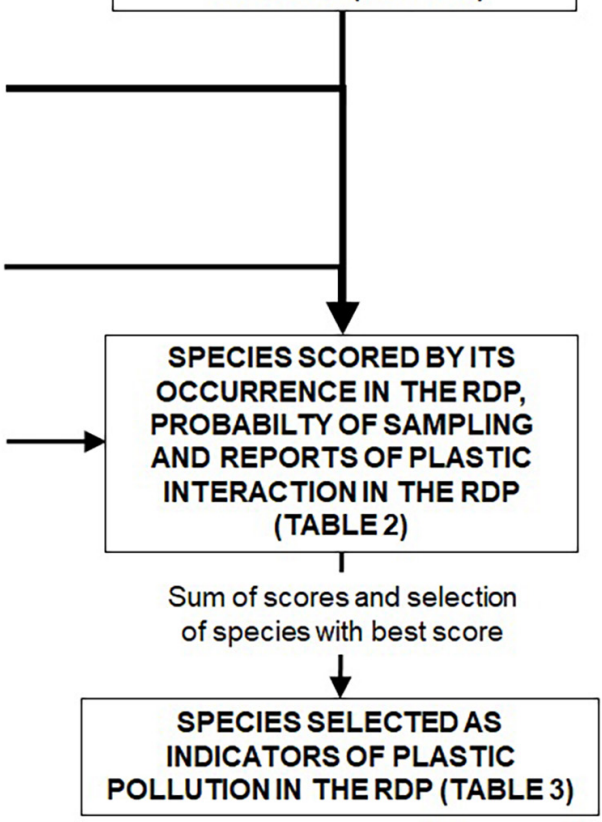

FIGURE 2 | Three-question structured scheme for selecting charismatic marine species as indicators of plastic pollution in the Río de la Plata estuarine area.

sites (e.g., through sampling of pellets in seabirds or feces in otariids). The probability of sampling was scored as "LOW" = 1 , "MEDIUM" = 2, or "HIGH" = 3 according to the literature and our own expertise. We also evaluated if the species has reports on interactions with plastic in the RdP and scored as: "NE" (non-existent reports $=1$ ), "UP" (unpublished reports $=2$ ), and "P" (published reports = 3). Then, we summed scores from the three questions (Q1, Q2, and Q3) to obtain a total score per species (Table 2).

Finally, we selected species that reached the highest total score (Ballschmiter et al., 1981; Azzarello and Van Vleet, 1987; Baldassin et al., 2016) as indicators. For each of the species selected, we evaluated the attributes previously identified in Table $\mathbf{1}$ according to the available knowledge on their ecology in the RdP. To guide our discussion on the species' strengths or weaknesses, we applied different colors green, yellow, or red- according to the specific attributes being suitable, vague, or unsuitable for an indicator species, respectively (Table 3 ).

\section{RESULTS}

\section{Key Attributes of Indicator Species of Plastic Pollution}

Based on our literature search, we identified 14 key attributes of indicator species of plastic pollution in the marine environment (Table 1). We grouped them according to three criteria that consider: (a) Intrinsic biological/ecological features of the species: data on the species abundance, distribution, core areas, movement, diet, and feeding habits.

(b) Methodological aspects that ensure sampling and interpretation of data: taxonomic status of the species, existence of background information, lethality of plastics, and retention of plastic in digestive tract of the species.

(c) Conservation status of the species and potential impact on the general public.

\section{Marine Charismatic Species and Plastic in the Warm Temperate Southwest Atlantic}

Sixty-two studies (60 published and 2 sources of unpublished data) reported the interaction of at least 47 charismatic marine species with plastics $>2 \mathrm{~mm}$ (hereafter, plastics) in the WTSA (Supplementary Table 1). This includes the five species of marine turtles present in the region, along with 11 and 31 species of marine mammals (cetaceans and pinnipeds) and seabirds (mainly procellariiforms, sphenisciforms, and charadriiforms), respectively (Table 2). Seabirds were the species with most reports as regards to ingestion and/or entanglement in plastic $(67.5 \%$ of reports), followed by marine turtles (20.0\%) and mammals $(12.5 \%)$. In the three taxa, most reports of interaction with plastic concentrated in southern Brazil (Figure 1).

Ingestion occurred in all species reported to interact with plastic in the WTSA, except for four species of seabirds with reports of entanglement only (Chroicocephalus maculipennis, 
TABLE 3 | Biological/ecological, methodological, and conservation attributes of species selected to be used as indicators of plastic pollution in the Río de la Plata estuarine area. Colors denote that attributes are suitable (green), vague (yellow), or unsuitable (red) for indicator species.

\begin{tabular}{|c|c|c|c|c|c|c|c|c|}
\hline & Chelonia mydas & Caretta caretta & $\begin{array}{l}\text { Dermochelys } \\
\text { coriacea }\end{array}$ & $\begin{array}{l}\text { Pontoporia } \\
\text { blainvillei }\end{array}$ & $\begin{array}{l}\text { Arctocephalus } \\
\text { australis }\end{array}$ & Otaria flavescens & $\begin{array}{l}\text { Larus } \\
\text { dominicanus }\end{array}$ & $\begin{array}{l}\text { Spheniscus } \\
\text { magellanicus }\end{array}$ \\
\hline \multicolumn{9}{|c|}{ Biological/ecological } \\
\hline Home range & $\begin{array}{l}\sim 250,000 \mathrm{~km}^{2} \text { in } \\
\text { the WTSA. Core } \\
\text { foraging areas of } \\
\sim 5,000 \mathrm{~km}^{2} \text { in the } \\
\text { RdP González } \\
\text { Carman et al., } 2012\end{array}$ & $\begin{array}{l}\sim 180,000 \mathrm{~km}^{2} \text { in } \\
\text { the WTSA. Core } \\
\text { foraging areas of } \\
\sim 8,000 \mathrm{~km}^{2} \text { in } \\
\text { the RdP } \\
\text { González Carman } \\
\text { et al., } 2016 \mathrm{a}\end{array}$ & $\begin{array}{l}\text { UN, but larger } \\
\text { than C. mydas } \\
\text { and C. caretta }\end{array}$ & $\begin{array}{l}\text { At least } \\
150 \mathrm{~km}^{2} \\
\text { Bordino et al., } \\
2008\end{array}$ & UN & $\begin{array}{l}\sim 36,000 \mathrm{~km}^{2} \text { in the RdP. } \\
\text { Core areas of } \\
\sim 5,400 \mathrm{~km}^{2} \text { Rodríguez } \\
\text { et al., } 2013\end{array}$ & UN & UN \\
\hline Mobility & $\begin{array}{l}\text { Long-distance } \\
\text { movements } \\
\text { ( thousands of km) } \\
\text { González Carman } \\
\text { et al., } 2012\end{array}$ & $\begin{array}{l}\text { Long-distance } \\
\text { movements } \\
\text { ( thousands of } \\
\text { km) González } \\
\text { Carman et al., } \\
2016 \text { a }\end{array}$ & $\begin{array}{l}\text { Long-distance } \\
\text { movements } \\
\text { ( thousands of } \\
\text { km) López- } \\
\text { Mendilaharsu } \\
\text { et al., } 2009\end{array}$ & $\begin{array}{l}\text { Local } \\
\text { movements } \\
\text { Bordino et al., } \\
2008\end{array}$ & $\begin{array}{l}\text { At least local } \\
\text { movements from } \\
\text { breeding colony } \\
\text { in the RdP } \\
\text { González Carman } \\
\text { et al., 2016b }\end{array}$ & $\begin{array}{l}\text { At least local movements } \\
\text { from breeding colony in } \\
\text { the RdP Rodríguez et al., } \\
\text { 2013; González Carman } \\
\text { et al., 2016b }\end{array}$ & UN & $\begin{array}{l}\text { Long-distance } \\
\text { movements } \\
\text { ( thousands of } \\
\text { km) Stokes } \\
\text { et al., } 2014\end{array}$ \\
\hline Taxonomy & Well-known & Well-known & Well-known & Well-known & Well-known & Well-known & Well-known & Well-known \\
\hline $\begin{array}{l}\text { State of } \\
\text { knowledge }\end{array}$ & Well-known & Well-known & Well-known & Well-known & Well-known & Well-known & Well-known & Well-known \\
\hline $\begin{array}{l}\text { Background } \\
\text { information on } \\
\text { interaction with } \\
\text { plastic }\end{array}$ & $\begin{array}{l}\text { YES González } \\
\text { Carman et al., } \\
\text { 2014a; Vélez-Rubio } \\
\text { et al., } 2018\end{array}$ & YES (this study) & YES (this study) & $\begin{array}{l}\text { YES Denuncio } \\
\text { et al., } 2011\end{array}$ & $\begin{array}{l}\text { YES Denuncio } \\
\text { et al., 2017a; } \\
\text { Franco-Trecu } \\
\text { et al., } 2017\end{array}$ & $\begin{array}{l}\text { YES Franco-Trecu et al., } \\
2017\end{array}$ & $\begin{array}{l}\text { YES Lenzi } \\
\text { et al., 2016; } \\
\text { Burgues et al., } \\
2020\end{array}$ & YES (this study) \\
\hline Lethality & Low (IN) & UN & UN & $\begin{array}{l}\text { Low (IN) } \\
\text { High (EN) }\end{array}$ & $\begin{array}{l}\text { Low (IN) } \\
\text { Low (EN) }\end{array}$ & $\begin{array}{l}\text { Low (IN) } \\
\text { Medium (EN) }\end{array}$ & $\begin{array}{l}\text { High (IN) } \\
\text { Medium (EN) }\end{array}$ & UN \\
\hline Retention time & UN & UN & UN & UN & UN & UN & UN & UN \\
\hline Sampling & $\begin{array}{l}\text { Easily identified, } \\
\text { regularly reported } \\
\text { stranded in } \\
\text { Argentina and } \\
\text { Uruguay coasts } \\
\text { González Carman } \\
\text { et al., 2011; } \\
\text { Vélez-Rubio et al., } \\
2013\end{array}$ & $\begin{array}{l}\text { Easily identified, } \\
\text { regularly reported } \\
\text { stranded in } \\
\text { Argentina and } \\
\text { Uruguay coasts } \\
\text { González Carman } \\
\text { et al., 2011; } \\
\text { Vélez-Rubio } \\
\text { et al., } 2013\end{array}$ & $\begin{array}{l}\text { Easily identified, } \\
\text { regularly reported } \\
\text { stranded in } \\
\text { Argentina and } \\
\text { Uruguay coasts } \\
\text { González Carman } \\
\text { et al., 2011; } \\
\text { Vélez-Rubio } \\
\text { et al., } 2013\end{array}$ & $\begin{array}{l}\text { Easily identified, } \\
\text { regularly } \\
\text { reported } \\
\text { stranded in } \\
\text { Argentina and } \\
\text { Uruguay coasts } \\
\text { (del Bene et al., } \\
2006 \text {, } \\
\text { unpublished } \\
\text { data) }\end{array}$ & $\begin{array}{l}\text { Easily identified, } \\
\text { regularly reported } \\
\text { stranded at least } \\
\text { in Argentina } \\
\text { (unpublished } \\
\text { data). } \\
\text { Opportunity for } \\
\text { sampling at } \\
\text { colony or resting } \\
\text { sites }\end{array}$ & $\begin{array}{l}\text { Easily identified, regularly } \\
\text { reported stranded at least } \\
\text { in Argentina (unpublished } \\
\text { data). Opportunity for } \\
\text { sampling at colony or } \\
\text { resting sites }\end{array}$ & $\begin{array}{l}\text { Easily identified. } \\
\text { Reported } \\
\text { stranded at } \\
\text { least in } \\
\text { Argentina } \\
\text { (unpublished } \\
\text { data). } \\
\text { Opportunity for } \\
\text { sampling at } \\
\text { colony or } \\
\text { resting sites }\end{array}$ & $\begin{array}{l}\text { Easily identified, } \\
\text { regularly } \\
\text { reported } \\
\text { stranded in } \\
\text { Argentina and } \\
\text { Uruguay coasts } \\
\text { (unpublished } \\
\text { data) }\end{array}$ \\
\hline
\end{tabular}


TABLE 3 | (Continued)

\begin{tabular}{|c|c|c|c|c|c|c|c|c|}
\hline & $\begin{array}{l}\text { Chelonia } \\
\text { mydas }\end{array}$ & $\begin{array}{l}\text { Caretta } \\
\text { caretta }\end{array}$ & $\begin{array}{l}\text { Dermochelys } \\
\text { coriacea }\end{array}$ & $\begin{array}{l}\text { Pontoporia } \\
\text { blainvillei }\end{array}$ & $\begin{array}{l}\text { Arctocephalus } \\
\text { australis }\end{array}$ & Otaria flavescens & $\begin{array}{l}\text { Larus } \\
\text { dominicanus }\end{array}$ & $\begin{array}{l}\text { Spheniscus } \\
\text { magellanicus }\end{array}$ \\
\hline \multicolumn{9}{|l|}{ Conservation } \\
\hline Public profile & $\mathrm{HIGH}$ & $\mathrm{HIGH}$ & $\mathrm{HIGH}$ & $\mathrm{HIGH}$ & $\mathrm{HIGH}$ & $\mathrm{HIGH}$ & MEDIUM & $\mathrm{HIGH}$ \\
\hline $\begin{array}{l}\text { Conservation } \\
\text { status }\end{array}$ & $\begin{array}{l}\text { LC Broderick } \\
\text { and Patricio, } \\
2019\end{array}$ & $\begin{array}{l}\text { LC Casale and } \\
\text { Marcovaldi, } \\
2015\end{array}$ & $\begin{array}{l}\text { CR Tiwari } \\
\text { et al., } 2013\end{array}$ & $\begin{array}{l}\text { VU Zerbini } \\
\text { et al., } 2017\end{array}$ & $\begin{array}{l}\text { LC } \\
\text { Cárdenas-Alayza } \\
\text { et al., } 2016 a\end{array}$ & $\begin{array}{l}\text { LC Cárdenas-Alayza } \\
\text { et al., 2016b }\end{array}$ & $\begin{array}{l}\text { LC BirdLife } \\
\text { International, } \\
2018 b\end{array}$ & $\begin{array}{l}\text { LC BirdLife } \\
\text { International, } \\
2020\end{array}$ \\
\hline
\end{tabular}

IN, ingestion; EN, entanglement; UN, unknown; LC, Least Concern; VU, vulnerable; CR, critically endangered.

Sterna hirundinacea, Chionis albus, and Nannopterum brasilianus; Supplementary Table 1). User plastics were ingested by the three taxa, whereas industrial pellets were only reported for marine turtles and seabirds (3.5 and 18.2\% of studies, respectively) (Figures 3A,E). Within user plastic, marine turtles and seabirds ingested plastic from all subcategories (sheetlike, threadlike, foamed plastics, fragments, and other), while marine mammals ingested fragments, sheetlike, and foamed plastics. Type of plastic could not be assessed in $2.4 \%$ of the reports.

In all taxa, the origin of plastics ingested was mostly from urban centers $-65.4,53.3$, and $58.8 \%$ for marine turtles, mammals, and seabirds, respectively - followed by fishing activities. Origin could not be assessed in $26.8 \%$ of the reports. Rates of incidence varied among taxa (Figures 3B,D,E), though it could not be assessed in $40.2 \%$ of reports.

Within marine turtles, Chelonia mydas had most reports of plastic ingestion $(61.3 \%)$ and was reported to ingest industrial plastic and all types of user plastic at rates of incidence that varied from low to very high. The other two marine turtle species -Caretta caretta and Dermochelys coriacea- accounted for $16.1 \%$ of the reports of plastic ingestion each one. They also ingested all types of user plastic at very low to medium rates in $C$. caretta and at low rates in $D$. coriacea at low rates (Figures 3A,B).

Within marine mammals, Pontoporia blainvillei (Pontoporiidae) and Arctocephalus australis (Otariidae) counted with most reports of plastic ingestion (both species 21.4\%), followed by Otaria flavescens (14.3\%). Contrary to marine turtles, marine mammals were reported to ingest some types of user plastic at very low or low rates (Figures 3C,D).

In the case of seabirds, Procellariidae species counted with most reports of plastic ingestion (56.1\%, mainly from Procellaria aequinoctialis and Ardenna gravis), followed by the families Diomedeidae (22.0\%, most reports of Thalassarche melanophris), Spheniscidae (9.8\%, one species Spheniscus magellanicus), and Laridae (8.5\%, most reports from Larus dominicanus). Similar to marine turtles, species of these families were reported to ingest all types of user plastic at rates of incidence that varied from very low to very high (Figures 3E,F).

Entanglement was recorded in marine mammals and seabirds, mostly in threadlike plastic from fishing activities (Supplementary Table 1). Type of plastic could not be assessed in $3.4 \%$ of the reports. Rates of incidence were very low in marine mammals and seabirds, and it could not be calculated in $69.0 \%$ of the reports.

\section{Marine Charismatic Species as Indicators of Plastic Pollution in the Río de la Plata}

Thirty-three out of the 47 charismatic species were considered to occur in the RdP (Table 2). From these species, 18, 9, and 6 had a low, medium, and high probability of sampling at beaches, port facilities, or reproductive colonies within the RdP, respectively. At the same time, 19 species do not have background information on plastic interaction in the RdP, while the rest have some kind of information (whether published or unpublished). Thus, species with the highest scores (Ballschmiter et al., 1981; Azzarello and Van Vleet, 1987; Baldassin et al., 2016) included marine turtles (C. mydas, C. caretta, and D. coriacea), mammals (P. blainvillei, A. australis, and O. flavescens), and seabirds (S. magellanicus and L. dominicanus).

The charismatic species selected as potential indicator species were similar in some of their key attributes and diverse in others (Table 3). All species had increasing abundances except for $P$. blainvillei and $O$. flavescens, whose populations are decreasing. Distribution was the widest for the three turtle species, while the rest had distributions restricted to coastal waters of South America. Within these distributions, home range areas were known only for C. mydas and C. caretta - with large (thousands of $\mathrm{km}^{2}$ ) core foraging areas -, and P. blainvillei with a very restricted home range. In fact, all species perform long distance movements except for P. blainvillei, A. australis, and O. flavescens, which known movement patterns are, to a greater or lesser degree, restricted to the RdP. Feeding habits among species were disparate including species that feed at or associated to the bottom (C. caretta, P. blainvillei, and O. flavescens), the surface (D. coriacea), and throughout the water column (S. magellanicus, C. mydas, and A. australis). Carnivory was the main type of diet for the species.

All species selected have well-established taxonomies (i.e., their identity as species is not under discussion), and are relatively well-studied in the WTSA. Except for S. magellanicus, all species had published reports of interaction with plastic in the RdP (Table 3). Based on studies revised (Supplementary Table 1), lethality was unknown for all species except for C. mydas, P. blainvillei, A. australis, and O. flavescens, which exhibit low lethality in terms of plastic ingestion. None of the species selected had known retention times of plastic in the digestive tract. Almost all species had a high public profile, and the most frequent conservation status was Least Concern. 


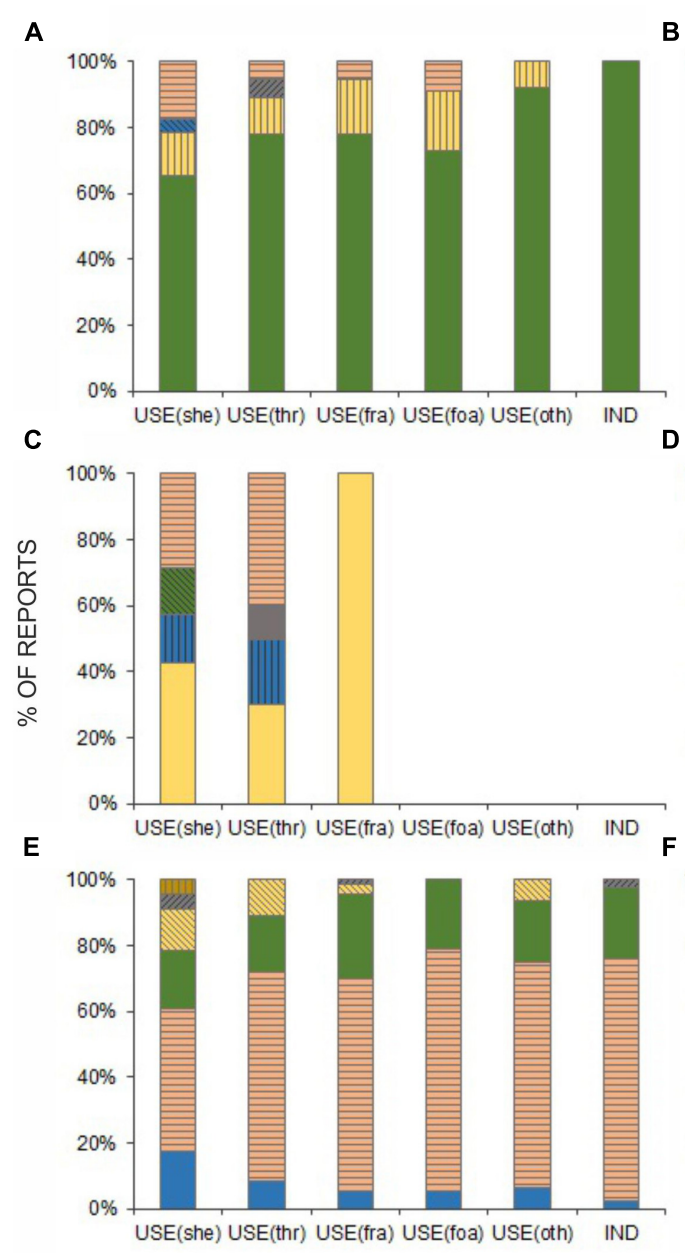

B
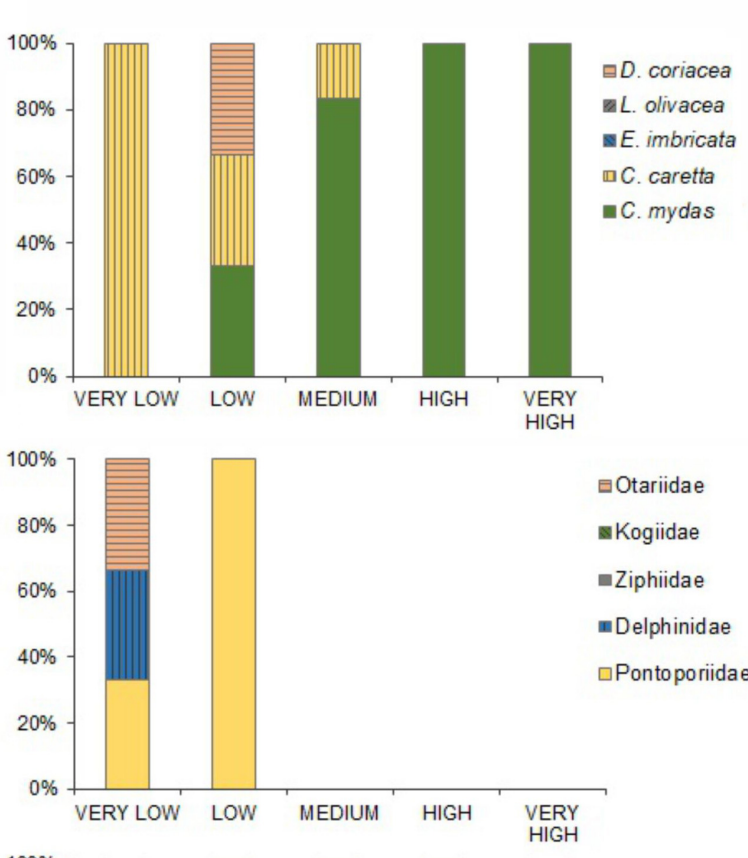

छOtariidae

Eogiidae

=Ziphiidae

=Delphinidae

$\neg$ Pontoporiidae

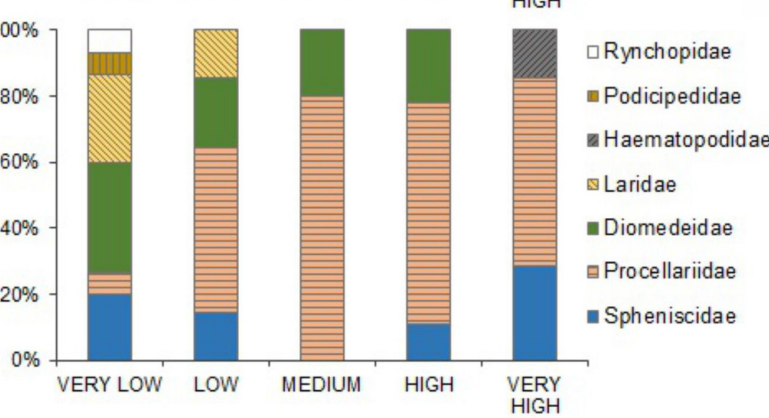

FIGURE 3 | Type and rate of incidence of plastic ingestion by species of marine turtles (A,B), and family of marine mammals (C,D) and seabirds (E,F) in the Warm Temperate Southwest Atlantic. IND, industrial plastic pellets; USE, user plastics (subcategories: she, sheetlike plastics; thr, threadlike plastics; foa, foamed plastics; fra, fragments; and oth, other); URB, plastics from urban centers; FISH, plastics from fishing activities.

\section{DISCUSSION}

In this study we evaluated for the first time the potential of certain charismatic marine species as indicators of plastic pollution in the Río de la Plata estuarine area, one of the largest and highest productive frontal systems of the WTSA. We identified 14 biological/ecological, methodological, and conservation attributes that indicator species of pollution in general, and plastic pollution in particular, should have (Table 1). We found that at least 47 charismatic marine species interact whether by ingestion or entanglement- with plastics in the study area. Eight of these species obtained the highest score according to their occurrence, probability of sampling and interaction with plastics in the RdP. The species were: C. mydas, C. caretta, D. coriacea, P. blainvillei, A. australis, O. flavescens, S. magellanicus, and L. dominicanus (Table 2). They shared some attributes of indicator species (e.g., they are relatively well studied in the $\mathrm{RdP}$ ), but differed in some critical ones related to their home range and mobility (Table 3). As we will discuss later, monitoring plastic pollution through a combination of species would enable a comprehensive and integral understanding of plastic pollution in this relevant area.

\section{Methodological Caveats}

Our exercise has some limitations regarding the scope of the literature review. We focused our attention on ingestion and entanglement as main interactions with plastics. The use of plastic for nest building in seabirds was not considered. We only focused on macro, meso and the largest size of microplastics, although ingestion of smaller microplastics has been reported for some charismatic marine species in the WTSA (e.g., Castro et al., 2018 and references therein).

Studies reporting entanglement in plastic represented a challenge. Even though we considered reports of animals entangled in remains of fishing gear with clear signs of abandonment (e.g., heavily biofouled ropes) or domestic plastics, this was difficult to assess in some cases. For example, it is not clear that entanglement observed in A. australis in the study area 
fully correspond to ALDFG fishing gear. On one hand, the species distribution highly overlaps with fishing grounds of Argentine and Uruguayan industrial fleets (Mandiola, 2015), so a direct interaction with fishing gear would seem plausible. But on the other hand, seals do not prey on the fisheries' target species (Vaz Ferreira, 1982), thus reducing the chance of a direct interaction. Other situations difficult to interpret are when fragments of gillnets containing entangled dead seabirds wash ashore, or when hooks are involved within the plastic entanglement material (e.g., Moore et al., 2009). As done in other reviews (e.g., Kühn et al., 2015; Ryan, 2018), we considered entanglement as all cases related to hooks, fishing lines, and fishing nets of undetermined origin. In the WTSA, this situation occurred more frequently in charadriiforms, particularly in Laridae species. According to observations of recreational fishers and co-occurring gulls, entanglement would occur in abandoned fishing (J. P. Seco Pon and M. P. Berón personal observations).

\section{Marine Charismatic Species as Indicators of Plastic Pollution}

The species selected in this study have a mix of suitable, vague and unsuitable attributes that affect their performance as indicator species of plastic pollution in the RdP in different ways. Even though is desirable that indicator species are abundant to allow long-term monitoring, the local decreasing abundances of P. blainvillei, O. flavescens, and S. magellanicus might not hamper their performance as indicators due to their long generation times. Generation times are between 10 and 15 years (Pacifici et al., 2013; BirdLife International, 2020), so there might be sufficient time until their local populations eventually decrease to an extent in which monitoring is no longer possible. Similarly, the restricted distributions of these species to coastal waters of South America make them unsuitable for comparing plastic pollution with distant areas of the globe, but they are still suitable for regional comparisons within the WTSA.

Maybe the most important differences among species selected were related to their home ranges and mobility. The highly migratory behavior and large home ranges of marine turtles are less suitable attributes for a potential indicator of plastic pollution in the RdP. Marine turtles arrive at the RdP from northern warmer waters off the coast of Brazil and West Africa (Billes et al., 2006; Prosdocimi et al., 2012, 2014a, 2015) in late austral spring, and remain foraging in the RdP and along the Buenos Aires province coast until early austral fall (Figure 1; López-Mendilaharsu et al., 2009; González Carman et al., 2011, 2012, 2016b). Therefore, marine turtles might be providing information on plastics present in the $\mathrm{RdP}$ and also in other nearby foraging areas (such as southern Buenos Aires province or southern Brazil). The penguin S. magellanicus exhibits a similar situation. During the winter, the species migrates from southern breeding areas to foraging areas of northern Argentina, Uruguay, or southern Brazil (Stokes et al., 1998, 2014; García-Borboroglu et al., 2010). Therefore, it is likely that $S$. magellanicus stranded in the RdP would provide information on plastics ingested not only locally, but also from nearby foraging areas.
For highly migratory species, such as marine turtles and S. magellanicus, it is relevant to have some knowledge on the passage time of food items (and plastics) to fully ascertain the geographical origin of the plastic ingested. In the case of juvenile C. mydas, passage time is ca. 20 days at $24.5^{\circ} \mathrm{C}$ independently of the type of diet (Campos and Cardona, 2020). Since mean water temperature is around $22-23^{\circ} \mathrm{C}$ during the warm months in the RdP (Guerrero et al., 1997; Lucas et al., 2005), retention time of plastics for neritic juvenile C. mydas foraging in this estuarine area might be at least 20 days. This is approximately three times lower than the mean residency time of the species ( $90.4 \pm 53.9$ days; unpublished data) in the RdP, so part of the plastics observed in C. mydas' digestive tracts (González Carman et al., 2014a; Vélez-Rubio et al., 2018) were definitively ingested in the study area. In neritic $C$. caretta, passage time was ca. 9 days at a range of temperatures of $16-23^{\circ} \mathrm{C}$, independently of the body size (Valente et al., 2008), so plastics observed in specimens from the RdP likely reflect local ingestion alone. Passage times are unknown for D. coriacea. Even though larger turtles may retain food items longer than smaller ones because they have longer intestines (Di Bello et al., 2006; but see Valente et al., 2008 and Heaton et al., 2016), D. coriacea's long digestive tract is also wider, so few, small plastic fragments may pass throughout the intestine without being retained.

In the case of seabirds, most information on passage times is available for procellariiforms (e.g., Ryan, 2015; van Franeker and Law, 2015; Provencher et al., 2017), although it varies widely. Some studies suggest that ingested plastics may be retained for 1-12 months, with an average of 4 months (van Franeker and Law, 2015; Provencher et al., 2017), while others estimated that $75 \%$ of plastics decompose in a month depending on the plastic types (van Franeker et al., 2011). Extrapolating this information to other seabirds is conflicting because many factors involved in digestion - such as gut length, gut morphology and feeding strategy - differed substantially between species (Jackson, 1992; Hilton et al., 2000). Despite this information is not available for penguins and gulls, passage times of penguins can be thought to be longer than for gulls due to their longer guts (scaled with body mass) and because flying birds are more restrained by weight (cf. Jackson, 1992).

On the contrary, marine mammals selected as potential indicators present movements and foraging activities restricted within the RdP estuarine area (Bordino et al., 2008; Rodríguez et al., 2013; González Carman et al., 2016a), suggesting that the interaction with plastic certainly occurred in the study area. Also, feeding experiments in captive animals demonstrates very short digestive passage times for P. blainvillei (18 $\pm 8 \mathrm{~h}$; Bassoi et al., 2018) and A. australis (9 \pm 3.4 h; Machado et al., 2008), supporting the idea of local plastic ingestion.

Particular feeding habits or diets may affect the probability of plastic ingestion (Schuyler et al., 2012; Nelms et al., 2016; Roman et al., 2019a,b). In the case of green and leatherback turtles, plastic ingestion likely occurs because it resembles natural prey items such as jellyfish or other soft-bodied organisms (Schuyler Q. et al., 2014; Schuyler Q. A. et al., 2014; Nelms et al., 2016). In the RdP, neritic-stage C. mydas has an omnivorous diet 
(with macroalgae and jellyfish as important diet items; González Carman et al., 2014b; Vélez-Rubio et al., 2016) and shows a high to very high rate of incidence of plastic ingestion (Figure 3B and Supplementary Table 1). Adults of $D$. coriacea also feed on jellyfish species in the RdP (Estrades et al., 2007), but few animals were examined for plastics to have an accurate estimation of the rate of incidence (Figure $3 \mathbf{B}$ and Supplementary Table 1). In contrast to these species, neritic-stage loggerheads feed on active benthic prey in the RdP, such as malacostracan crustaceans and gastropod mollusks (Martinez Souza, 2009), and shows a very low to medium rate of incidence of plastic ingestion (Figure $3 \mathbf{B}$ and Supplementary Table 1).

In the case of marine mammals, the probability of plastic ingestion might be related to feeding strategies in the water column. Di Beneditto and Ramos (2014) suggested that species with demersal-benthic trophic habits might be more impacted than species feeding on pelagic prey. In the RdP estuarine area, $P$. blainvillei feeds on demersal and small prey - such as juvenile teleost fish and small cephalopods (Denuncio et al., 2017b) -, and A. australis feeds on pelagic fish species (e.g., Franco-Trecu et al., 2014). Consequently, plastic ingestion rate in P. blainvillei is at least 3 times higher than that of $A$. australis ( $>30 \%$ against $7 \%$ for dolphins and fur seals, respectively; Denuncio et al., 2011, 2017a). Even though plastic concentrations drop exponentially with water depth (Reisser et al., 2014), the higher rate of incidence of P. blainvillei compared to that of seals could be due to the shallow depth $(<20 \mathrm{~m})$ of the RdP estuarine area and existence of a bottom salinity front accumulating plastics (Mianzan et al., 2001; Acha et al., 2003). The complexity of the stomach of dolphins against the typical carnivore stomach for pinnipeds (Yamasaki et al., 1974) could also explain P. blainvillei's higher rate of incidence.

The interaction of seabirds with plastic depends on several ecological drivers such as taxonomy, foraging ecology, diet, and exposure (Tavares et al., 2017; Roman et al., 2019a,b). Procellariiform seabirds (albatross and petrels) are among the group with the highest incidence of ingestion, and thus they have been well studied compared to sphenisciforms and charadriiforms in which ingestion has been reported at comparatively lower rates (Roman et al., 2019a; Kühn and van Franeker, 2020). Planktivores have a higher incidence of ingesting plastics than do piscivores as the former are more likely to confuse plastic pellets with copepods, euphausiids, and cephalopods (Azzarello and Van Vleet, 1987). Tavares et al. (2017) assessed the incidence of plastic ingestion in five guilds of seabirds - pursuit divers, pursuit plungers, surface seizers, surface plungers, and dippers - and found that the incidence of debris was higher in birds feeding predominantly at intermediate (3$6 \mathrm{~m})$ and deep (20-100 m) waters than those feeding at surface $(<2 \mathrm{~m})$ (cf. Wilcox et al., 2015). This includes species such as S. magellanicus along with albatross and petrels.

In the WTSA, Di Beneditto and Siciliano (2017) suggest that S. magellanicus might ingest plastic while diving throughout the water column, but more likely in surface waters where their preferred prey of fish and squid inhabit. Unfortunately, this is unknown for the RdP estuarine area due to the lack of published reports of plastic ingestion (Table 2). But given the known migratory pattern of the species, if penguins stranded along the coast of southern Brazil present plastic in their stomachs (e.g., Brandão et al., 2011; Marques et al., 2018; Ewbank et al., 2020), it seems plausible that stranded penguins along the coast of the RdP have plastic in their guts as well. The absence of information on plastics in penguins found dead in the RdP is likely due to lack of examination.

\section{Multispecies Indicator of Plastic Pollution in the Río de la Plata Estuarine Area}

Despite the strengths and weaknesses discussed above, plastic pollution monitoring in the $\mathrm{RdP}$ estuarine area could be performed through a combination of species. In this sense, what constitutes a weakness for a species could be underpinned by other species' strengths. For example:

- Different species integrate plastic at different geographic scales. Only P. blainvillei, O. flavescens, and A. australis strictly reflect local plastic pollution due to their restricted home ranges and migratory movements; while the rest of the species integrates, in variable degrees, pollution originated locally and in nearby regions (both to the north and south of the RdP). But in the case of marine turtles, sampling could be performed in certain months when finding plastic ingested within the study area is more likely. For example, if marine turtles occur in the $\mathrm{RdP}$ estuarine area from September to May - and passage times of food items are supposed to be of 1-2 months approximately -, then sampling could be done during January and February.

- Different species sample different levels of the water column. While C. caretta, O. flavescens, and P. blainvillei are demersal predators potentially sampling plastic near or at the bottom, C. mydas, S. magellanicus, A. australis, and $D$. coriacea might sample plastic throughout the entire water column, especially within the study area where depth is $<20 \mathrm{~m}$.

- Different species have different sensitivity to detect changes. In the WTSA, rates of incidence of plastic ingestions vary from low in S. magellanicus (with some exceptions), A. australis, O. flavescens, P. blainvillei, and D. coriacea, to moderate in C. caretta and high in C. mydas (Figure 3 and Supplementary Table 1). We believe that a good set of indicator species should have species with high, medium and low rates of incidence. Even though species with low rates of incidence (and small amounts of plastic ingested such as marine mammals) make sampling and counting difficult, thus becoming less sensitive to plastic pollution, selecting only species with high incidence of occurrence such as C. mydas along the WTSA - would hinder the observation of changes. If the plastic load of the ecosystem increases, changes in rates of incidence would be unnoticed if the species reported high values from the beginning of the monitoring. And if the plastic load decreases, it would take a long time, or a large change in the plastic load, to effectively see a change in the species' rate of incidence if it is already "saturated." 
In addition to this complementarity, there are other reasons to consider the potential of a multispecies indicator. On the one hand, what makes them a multispecies indicator is the fact that they are regularly found stranded along the coasts of Uruguay and northern Argentina so long-term monitoring and sampling are guaranteed. Besides, all species have body sizes that make them easily necropsied in the beach if found dead. In the case of live animals, all the species have been rehabilitated in local rescue centers so data collected from dead animals can be complemented with in-depth veterinary analysis (radiology, etc.) and excreta examination. Research projects on these species exist both in Argentina and Uruguay, as well as in the rest of the WTSA. All species have high public profile offering great potential to raise awareness of plastic pollution in the society.

On the other hand, some of the selected species such as C. mydas and the seals are thought to be associated to the frontal system of the RdP (e.g., Rodríguez et al., 2013; González Carman et al., 2014a), where plastic from upriver urban centers accumulate (Acha et al., 2003). This association might increase species' exposure, and thus susceptibility, to plastics (e.g., Darmon et al., 2017). In this sense, we suggest that another key attribute of indicator species of plastic pollution could be that of exposure to plastics, which can also occur in a variety of situations such as species proximity to large urban areas, or association to fishing activities or port facilities.

Given the above, implementation of this multispecies indicator of plastic pollution needs standardization of sampling protocols among local research groups in relation to international standards (e.g., Provencher et al., 2017). Consensus should be reached on the reporting procedure (mean, median, range, standard deviation, inclusion of zero values) needed to reliable estimate different metrics -e.g., frequency of occurrence, sample size, monitoring effort, number of plastic pieces, mass of plastic pieces - at the level of species or family at both coasts of the RdP estuarine area. Besides, the establishment of a panel of experts and a permanent monitoring schedule of stranding in the frame of the plans of action for marine turtles, mammals, and seabirds enacted in Argentina and Uruguay. Valuable information would be gathered if a long-term and systematic monitoring of stranded animals is established in the area.

A first step to evaluate the performance of the species selected as indicators of plastic pollution in the RdP estuarine area could be the creation of a baseline for the occurrence of plastic bags in the digestive tracts of the species. Apart from the policy at the regional and national levels adopted by Argentina and Uruguay (e.g., UNCLOS, CBD, Annex V of MARPOL 73/78, London Convention, national household management laws; González Carman et al., 2015; Lozoya et al., 2015), specific legislation aiming to ban or progressively reduce plastic bags utilization is the most extended and respected measure in the study area. Buenos Aires enacted the Plastic Containers Law in 2008, and similar laws were passed in Buenos Aires city (2016) and Uruguay (2018). In fact, pictures of charismatic marine fauna such as marine turtles are part of the national reports raising awareness on plastic pollution.

Despite some constraints, charismatic marine megafauna presents a unique opportunity to increase awareness on marine plastic pollution (Bonanno and Orlando-Bonaca, 2018). Marine turtles such as $C$. caretta is already used as indicator of plastic pollution in the Mediterranean Sea (Camedda et al., 2014; Campani et al., 2014). Other species such as D. coriacea and C. mydas might also be useful indicators based on observations on changing ingestion rates possible due to changes in the environment (Mrosovsky et al., 2009; Schuyler Q. et al., 2014). Marine mammals are also considered as prime sentinels of marine health for many anthropogenic pollutants and climate change (Moore, 2008; Bossart, 2011). With regard to plastics, only filter-feeding and suction feeder cetaceans such as fin whales (Balaenoptera physalus) and sperm whales (Physeter macrocephalus) are considered good indicators of micro and macroplastic, respectively (Fossi et al., 2020).

As with marine mammals, seabirds such as penguins also have a long history of use as indicator species of different types of pollutants (Ballschmiter et al., 1981; Finger et al., 2015) such as oil (Gandini et al., 1994; García-Borboroglu et al., 2006), persistent organic pollutants (Baldassin et al., 2016), and trace metals (Espejo et al., 2014, 2020). In fact, the rate of incidence of plastic ingestion in S. magellanicus increased from 16 to $89 \%$ in the WTSA during the period 2000-2008 (Pinto et al., 2007; Brandão et al., 2011; Di Beneditto et al., 2015). However, S. magellanicus is thought to be a poor indicator of the exact location of oil pollution due to their extensive travels (García-Borboroglu et al., 2006). If this is also the case for plastic pollution, further research is needed, particularly to know the species' foraging hotspots in the study area. Lastly, special care should be taken with L. dominicanus (Acampora et al., 2016). The species feed at refuse dumps (Yorio et al., 2020), so the origin of the plastic ingested could not be attributed unequivocally to the marine environment. Besides, most gulls regurgitate one pellet per meal (Barrett et al., 2007), so plastics found in pellets or stomachs are likely a small portion of the plastic consumed. Lastly, gulls aggregate in mixed groups at roosts and resting sites, so pellets can sometimes not be allocated to a specific species (Barrett et al., 2007).

In this study we aimed to give insights into the potentials and limits of using charismatic marine species as indicators of plastic pollution in one of the most biological and economic relevant environments of the WTSA. But we only advanced the first steps. Management measures should focus on calling a panel of local experts to discuss the species selected as indicators and to plan next research efforts focused on, for example, exploring teleost and elasmobranch species as indicators of plastic pollution. So far, microplastic ingestion has been recorded in 11 species of coastal freshwater fish of the RdP estuarine area (Pazos et al., 2017), so potential of transfer within the trophic web exists. Certainly, further studies on passage time are needed for the eight marine charismatic species identified in order to define the spatial-scale resolution in which they would be good indicators of plastic pollution in the RdP. The analytical exercise proposed in this study can be replicated in other important ecosystems where plastic pollution is increasing its pervasiveness.

\section{DATA AVAILABILITY STATEMENT}

The raw data supporting the conclusions of this article will be made available by the authors, without undue reservation. 


\section{AUTHOR CONTRIBUTIONS}

VGC and PD contributed to the conception and design of the study. VGC led manuscript preparation, analyzed the data, design the figures, and wrote most part of the manuscript. SR-H, KÁ, and MPB contributed with unpublished data. MV revised the literature of objective 1 and built Table 1. VGC, PD, MPB, SR-H, and KÁ built Tables 2 and 3. VGC, PD, MV, and MPB worked in the Supplementary Material. PD and MPB assisted with writing some sections of discussion. All authors discussed the contents of the manuscript and contributed to manuscript revision.

\section{FUNDING}

VGC and PD received funding from FONCyT (VGC: PICT 2099-2013 and PICT 1575-2017; PD: PICT 24552015). MPB was sponsored by the UNMdP (15/3795, EXA 842/17). Research activities of SR-H and KÁ were supported by Parque Educativo Mundo Marino. VGC was supported by Instituto Nacional de Investigación y Desarrollo Pesquero. VGC, PD and MPB were supported by Consejo Nacional de Investigaciones Científicas y

\section{REFERENCES}

Acampora, H., Lyashevska, O., Van Franeker, J. A., and O’Connor, I. (2016). The use of beached bird surveys for marine plastic litter monitoring in Ireland. Mar. Environ. Res. 120, 122-129. doi: 10.1016/j.marenvres.2016.08.002

Acha, E. M., Mianzan, H. W., Iribarne, O., Gagliardini, D. A., Lasta, C., and Daleo, P. (2003). The role of the Río de la plata bottom salinity front in accumulating debris. Mar. Pollut. Bull. 46, 197-202. doi: 10.1016/S0025-326X(02)00356-9

Acha, E. M., Mianzan, H., Guerrero, R., Carreto, J., Giberto, D., Montoya, N., et al. (2008). An overview of physical and ecological processes in the Rio de la Plata Estuary. Cont. Shelf Res. 28, 1579-1588. doi: 10.1016/j.csr.2007.01.031

Aguirre, A. A., and Lutz, P. L. (2004). Marine turtles as sentinels of ecosystem health: is fibropapillomatosis an indicator? EcoHealth 1, 275-283.

Albert, C., Luque, G. M., and Courchamp, F. (2018). The twenty most charismatic species. PLoS One 13:e0199149. doi: 10.1371/journal.pone.0199149

Andrades, R., Pegado, T., Godoy, B. S., Reis-Filho, J. A., Nunes, J. L., Grillo, A. C., et al. (2020). Anthropogenic litter on Brazilian beaches: baseline, trends and recommendations for future approaches. Mar. Pollut. Bull. 151:110842. doi: 10.1016/j.marpolbul.2019.110842

Avery-Gomm, S., Borrelle, S. B., and Provencher, J. F. (2018). Linking plastic ingestion research with marine wildlife conservation. Sci. Total Environ. 63, 1492-1495. doi: 10.1016/j.scitotenv.2018.04.409

Azzarello, M. Y., and Van Vleet, E. S. (1987). Marine birds and plastic pollution. Mar. Ecol. Progr. Ser. 37, 295-303.

Azpiroz, A. B., Jiménez, S., and Alfaro, M. (2017). Libro Rojo de las Aves del Uruguay. Biología y conservación de las aves en peligro de extinción a nivel nacional. Categorías "Extinto a Nivel Regional", "En Peligro Crítico" y "En Peligro. Montevideo: DINAMA and DINARA.

Baldassin, P., Taniguchi, S., Gallo, H., Maranho, A., Kolesnikovas, C., Amorin, D. B., et al. (2016). Persistent organic pollutants in juvenile magellanic penguins (Spheniscus magellanicus) in South America. Chemosphere 149, 391-399. doi: 10.1016/j.chemosphere.2016.01.016

Ballschmiter, K., Scholz, C., Buchert, H., Zell, M., Figge, K., Polzhofer, K., et al. (1981). Studies of the global baseline pollution. Fresen. Z. Anal. Chem. 309, $1-7$.

Barrett, R. T., Camphuysen, K., Anker-Nilssen, T., Chardine, J. W., Furness, R. W., Garthe, S., et al. (2007). Diet studies of seabirds: a review and recommendations. ICES J. Mar. Sci. 64, 1675-1691. doi: 10.1093/icesjms/fsm152
Técnicas (CONICET). MV had a scholarship from Consejo Interuniversitario Nacional of Argentina. This was INIDEP contribution no. 2250.

\section{ACKNOWLEDGMENTS}

This manuscript would not be possible without the effort of many fishermen, researchers, and technicians who provided animals, collected samples, and executed fieldwork. We are grateful to Ignacio M. Bruno, Roberto Ubieta, Gaston Delgado, Sergio Chileski, Vanesa Traverso, Eugenia Argañaraz, Melisa Cerles, Ricardo Bastida, Alan Rosenthal, park rangers of Faro Querandí, and members of the Marine Mammal Research Group (IIMYC, UNMDP-CONICET).

\section{SUPPLEMENTARY MATERIAL}

The Supplementary Material for this article can be found online at: https://www.frontiersin.org/articles/10.3389/fmars. 2021.699100/full\#supplementary-material

Bartell, S. M. (2006). Biomarkers, bioindicators, and ecological risk assessmenta brief review and evaluation. Environ. Bioindicators 1, 60-73. doi: 10.1080/ 15555270591004920

Bastida R, Rodríguez D, Secchi E and da Silva V. (2007). Mamíferos Marinos Sudamericanos. Buenos Aires: Vázquez Mazzini Press.

Bassoi, M., Shepard, J., and Secchi, E. R. (2018). Opportunistic feeding experiment in a captive franciscana (Pontoporia blainvillei): assessing gastrointestinal transit time and gastric digestion. Lat. Am. J. Aquat. Mammals 13, 15-22. doi: $10.5597 / 00244$

Becker, P. H., Furness, R. W., and Tasker, M. L. (2003). "Seabirds as monitors of marine pollution," in Seabirds as Monitors of the Marine Environment, eds M. L. Tasker and R. W. Furness (Copenhagen: ICES Cooperative Research Report), $3-25$.

Burgues, M. F., Lenzi, J., Machín, E., Genta, L., and Teixeira De Mello, F. (2020). Temporal variation of Kelp Gull's (Larus dominicanus) diet on a coastal island of the Rio de la Plata Estuary, Uruguay: refuse as an alternative food source. Waterbirds 43, 65-74.

Billes, A., Fretey, J., Verhage, B., Huijbregts, B., Giffoni, B., Prosdocimi, L., et al. (2006). First evidence of leatherback movement from Africa to South America. Mar. Turtle New. 111, 13-14.

BirdLife International (2017). Chionis albus (Amended Version of 2017 Assessment). The IUCN Red List of Threatened Species 2017: e.T22693556A118854999. Available online at: https://dx.doi.org/10.2305/IUCN.UK.2017-3.RLTS. T22693556A118854999.en (accessed June 12, 2021).

BirdLife International (2018a). Calonectris edwardsii. The IUCN Red List of Threatened Species 2018: e.T22729421A132660464. Available online at: https://dx.doi.org/10.2305/IUCN.UK.2018-2.RLTS.T22729421A132660464.en (accessed February 12, 2021).

BirdLife International (2018b). Larus dominicanus. The IUCN Red List of Threatened Species 2018: e.T22694329A132542863. Available online at: https://dx.doi.org/10.2305/IUCN.UK.2018-2.RLTS.T22694329A132542863.en (accessed June 20, 2021).

BirdLife International (2020). Spheniscus magellanicus. The IUCN Red List of Threatened Species 2020: e.T22697822A157428850. Available online at: https://dx.doi.org/10.2305/IUCN.UK.2020-3.RLTS.T22697822A157428850.en (accessed February 20, 2021).

Blettler, M. C. M., Garello, N., Ginon, L., Abrial, E., Espinola, L. A., and Wantzen, K. M. (2019). Massive plastic pollution in a mega-river of a developing country: 
sediment deposition and ingestion by fish (Prochilodus lineatus). Environ. Pollut. 255:113348. doi: 10.1016/j.envpol.2019.113348

Blettler, M. C. M., Ulla, M. A., Rabuffetti, A. P., and Garello, N. (2017). Plastic pollution in freshwater ecosystems: macro-, meso-, and microplastic debris in a floodplain lake. Environ. Monit. Assess. 189:581. doi: 10.1007/s10661-0176305-8

Bonanno, G., and Orlando-Bonaca, M. (2018). Perspectives on using marine species as bioindicators of plastic pollution. Mar. Pollut. Bull. 137, 209-221. doi: 10.1016/j.marpolbul.2018.10.018

Bordino, P., Wells, R., and Stamper, M. (2008). Satellite Tracking of Franciscana Dolphins Pontoporia blainvillei in Argentina: Preliminary Information on Ranging, Diving and Social Patterns. Available online at: https://delfinfranciscana.org/wp-content/uploads/2017/01/Bordino-et-alIWC-2008.pdf (accessed February 20, 2021).

Borrelle, S. B., Ringma, J., Law, K. L., Monnahan, C. C., Lebreton, L., Mcgivern, A., et al. (2020). Predicted growth in plastic waste exceeds efforts to mitigate plastic pollution. Science 369, 1515-1518. doi: 10.1126/science.aba3656

Bossart, G. D. (2011). Marine mammals as sentinel species for oceans and human health. Vet. Pathol. 48, 676-690. doi: 10.1177/0300985810388525

Broderick, A., and Patricio, A. (2019). Chelonia mydas (South Atlantic subpopulation). The IUCN Red List of Threatened Species 2019: e.T142121866A142086337. Available online at: https://dx.doi.org/10.2305/ IUCN.UK.2019-2.RLTS.T142121866A142086337.en (accessed February 20, 2021).

Brandão, M. L., Braga, K. M., and Luque, J. L. (2011). Marine debris ingestion by Magellanic penguins, Spheniscus magellanicus (Aves: Sphenisciformes), from the Brazilian coastal zone. Mar. Pollut. Bull. 62, 2246-2249. doi: 10.1016/j. marpolbul.2011.07.016

Burger, J., and Gochfeld, M. (2004). Marine birds as sentinels of environmental pollution. EcoHealth 1, 263-274. doi: 10.1007/s10393-004-0096-4

Camedda, A., Marra, S., Matiddi, M., Massaro, G., Coppa, S., Perilli, A., et al. (2014). Interaction between loggerhead sea turtles (Caretta caretta) and marine litter in Sardinia (Western Mediterranean Sea). Mar. Environ. Res. 100, 25-32. doi: 10.1016/j.marenvres.2013.12.004

Campani, T., Baini, M., Giannetti, M., Cancelli, F., Mancusi, C., Serena, F., et al. (2014). Presence of plastic debris in loggerhead turtle stranded along the Tuscany coasts of the Pelagos Sanctuary for Mediterranean Marine Mammals (Italy). Mar. Pollut. Bull. 74, 225-230. doi: 10.1016/j.marpolbul.2013.06.053

Campos, P., and Cardona, L. (2020). Trade-offs between nutritional quality and abundance determine diet selection in juvenile benthic green turtles. J. Exp. Mar. Biol. Ecol. 527:151373. doi: 10.1016/j.jembe.2020.151373

Campagna, J., Lewis, M. N., González Carman, V., Campagna, C., Guinet, C., Johnson, M., et al. (2020). Ontogenetic niche partitioning in southern elephant seals from Argentine Patagonia. Mar. Mammal Sci. 37, 631-651. doi: 10.1111/ mms. 12770

Cárdenas-Alayza, S., Oliveira, L., and Crespo, E. (2016a). Arctocephalus australis. The IUCN Red List of Threatened Species 2016: e.T2055A45223529. Available online at: https://dx.doi.org/10.2305/IUCN.UK.2016-1.RLTS. T2055A45223529.en (accessed June 20, 2021).

Cárdenas-Alayza, S., Crespo, E., and Oliveira, L. (2016b). Otaria byronia. The IUCN Red List of Threatened Species 2016: e.T41665A61948292. Available online at: https://dx.doi.org/10.2305/IUCN.UK.2016-1.RLTS.T41665A61948292.en (accessed June 20, 2021).

Caro, T. M., and O'Doherty, G. (1999). On the use of surrogate species in conservation biology. Conserv. Biol. 13, 805-814. doi: 10.1046/j.1523-1739. 1999.98338.x

Caro, T. (2010). Conservation by Proxy: Indicator, Umbrella, Keystone, Flagship, and Other Surrogate Species. Washington, DC: Island Press.

Castro, R. O., Da Silva, M. L., and De Araújo, F. V. (2018). Review on microplastic studies in Brazilian aquatic ecosystems. Ocean Coast. Manage. 165, 385-400. doi: 10.1016/j.ocecoaman.2018.09.013

Casale, P., and Marcovaldi, M. (2015). Caretta caretta (South West Atlantic subpopulation). The IUCN Red List of Threatened Species 2015: e.T84191235A84191397. Available online at: https://www.iucnredlist.org/ species/84191235/84191397 (accessed February 20, 2021).

Cole, M., Lindeque, P., Halsband, C., and Galloway, T. S. (2011). Microplastics as contaminants in the marine environment: a review. Mar. Pollut. Bull. 62, 2588-2597. doi: 10.1016/j.marpolbul.2011.09.025
Copello, S., Seco Pon, J. P., and Favero, M. (2013). Use of marine space by Blackbrowed albatrosses during the non-breeding season in the Southwest Atlantic Ocean. Estuar. Coast. Shelf 123, 34-38.

Crespo, E. A., de Oliveira, L. R., and Sepúlveda, M. (2021). "South American Sea Lion (Otaria flavescens, Shaw 1800)," in Ecology and Conservation of Pinnipeds in Latin America, eds G. Heckel and Y. Schramm (Cham: Springer). doi: 10. 1007/978-3-030-63177-2_

Darmon, G., Miaud, C., Claro, F., Doremus, G., and Galgani, F. (2017). Risk assessment reveals high exposure of sea turtles to marine debris in french mediterranean and metropolitan atlantic waters. Deep-Sea Res. Pt. II 141, 319-328. doi: 10.1016/j.dsr2.2016.07.005

Defeo, O., Puig, P., Horta, S., and Álava, A. D. (2011). "Coastal fisheries of uruguay," in Coastal Fisheries of Latin America and the Caribbean, eds S. Salas, R. Chuenpagdee, A. Charles, and J. C. Seijo (Italy: FAO Fish. Tech.), 357-384.

del Bene, D., Little, V., Rossi, R., and Le Bas, A. (2006). "Revisión preliminar de registros de varamientos de cetáceos en la costa uruguaya de 1934 a 2005," in Bases Para la Conservación y el Manejo en la Costa Uruguaya, eds R. Menafra, L. Rodríguez-Gallego, F. Scarabino, and D. Conde (Montevideo, UY: Vida Silvestre Uruguay), 297-303.

Dellabianca, N. A., and Gribaudo, C. A. (2019). "Balaenoptera physalus," in Categorización 2019 de los Mamíferos de Argentina según su riesgo de Extinción. Lista Roja de los Mamíferos de Argentina. Available online at: http://cma.sarem. org.ar (accessed February 15, 2021).

Denuncio, P., Bastida, R., Dassis, M., Giardino, G., Gerpe, M., and Rodríguez, D. (2011). Plastic ingestion in Franciscana dolphins, Pontoporia blainvillei (Gervais and d'Orbigny, 1844), from Argentina. Mar. Pollut. Bull. 62, 18361841. doi: 10.1016/j.marpolbul.2011.05.003

Denuncio, P., Mandiola, M. A., Pérez Salles, S. B., Machado, R., Ott, P. H., De Oliveira, L. R., et al. (2017a). Marine debris ingestion by the South American fur seal from the southwest atlantic Ocean. Mar. Pollut. Bull. 122, 420-425. doi: 10.1016/j.marpolbul.2017.07.013

Denuncio, P., Paso Viola, M. N., Machovsky-Capuska, G., Blasina, G., Machado, R., Polizzi, P., et al. (2017b). Population variance in prey, diet and they macronutrient composition of an endangered marine mammal, the Franciscana dolphin. J. Sea. Res. 129, 70-79. doi: 10.1016/j.seares.2017.05.008

Denuncio, P. E., Paso Viola, M. N., Cáceres-Saez, I., Cappozzo, H. L., Rodríguez, D., and Mandiola, A. (2019). "Pontoporia blainvillei," in Categorización 2019 de los Mamíferos de Argentina Según su riesgo de Extinción. Lista Roja de los Mamiferos de Argentina. Available online at: http://cma.sarem.org.ar (accessed February 15, 2021).

Di Bello, A., Valastro, C., Staffieri, F., and Crovace, A. (2006). Contrast radiography of the gastrointestinal tract in sea turtles. Vet. Radiol. Ultrasoun. 47, 351-354. doi: 10.1111/j.1740-8261.2006.00152.x

Di Beneditto, A. P. M., and Ramos, R. M. A. (2014). Marine debris ingestion by coastal dolphins: what drives differences between sympatric species? Mar. Pollut. Bull. 83, 298-301. doi: 10.1016/j.marpolbul.2014.03.057

Di Beneditto, A. P. M., and Siciliano, S. (2017). Marine debris boost in juvenile Magellanic penguins stranded in south-eastern Brazil in less than a decade: insights into feeding habits and habitat use. Mar. Pollut. Bull. 125, 330-333. doi: 10.1016/j.marpolbul.2017.09.044

Di Beneditto, A. P. M., Dos Santos, R. A., Rosa, K. R., and Siciliano, S. (2015). Magellanic penguins: stomach contents and isotopic profiles to assess the feeding demands of juveniles in a wintering area off Brazil. J. Mar. Biol. Assoc.UK. 95, 423-430. doi: 10.1017/S0025315414001532

Ducarme, F., Luque, G. M., and Courchamp, F. (2013). What are "charismatic species" for conservation biologists? BioSci. Master Rev. 10, 1-8.

Durant, J. M., Hjermann, D. Ø, Frederiksen, M., Charrassin, J. B., Le Maho, Y., Sabarros, P. S., et al. (2009). Pros and cons of using seabirds as ecological indicators. Clim. Res. 39, 115-129. doi: 10.3354/cr00798

Eder, E. B., Negrete, J., Gribaudo, C. A., Daneri, G. A., Marín, M. R., and Grandi, M. F. (2019). "Mirounga leonina" in Categorización 2019 de los Mamiferos de Argentina Según su Riesgo de Extinción. Lista Roja de los Mamíferos de Argentina. Available online at: http://cma.sarem.org.ar (accessed February 15, 2021).

Elías, I., Carozza, C., Giácomo, E. E. D., Isla, M. S., Orensanz, J. M. L., Parma, A. M., et al. (2011). "Coastal fisheries of argentina," in Coastal Fisheries of Latin America and the Caribbean, eds S. Salas, R. Chuenpagdee, A. Charles, and J. C. Seijo (Italy: FAO Fish. Tech.), 13-48. 
Espejo, W., Celis, J., González-Acuña, D., Jara, S., and Barra, R. (2014). Concentration of trace metals in excrements of two species of penguins from different locations of the Antarctic Peninsula. Polar Biol. 37, 675-683. doi: 10.1007/s00300-014-1468-z

Espejo, W., Ferreira Braz, B., Santelli, R., Padilha, J., de, A., Dorneles, P., et al. (2020). Trace metal concentrations and body condition in adult Adelie penguins (Pygoscelis adeliae) from the western Antarctic Peninsula. Lat. Am. J. Aquat. Res. 48, 886-894. doi: 10.3856/vol48-issue5-fulltext- 2455

Estrades, A., López-Mendilaharsu, M., and Fallabrino, A. (2007). Dermochelys coriacea (Leatherback Sea turtle). Diet. Herp. Review 38:330.

Ewbank, A. C., Sacristán, C., Costa-Silva, S., Antonelli, M., Lorenço, J. R., Nogueira, G. A., et al. (2020). Postmortem findings in Magellanic penguins (Spheniscus magellanicus) caught in a drift gillnet. BMC Veter. Res. 16:1-10. doi: 10.1186/ s12917-020-02363-x

Favero, M., and Silva Rodríguez, M. P. (2005). Estado actual y conservación de aves pelágicas que utilizan la plataforma continental argentina como área de alimentación. Hornero 20, 95-110.

Favero, M., Copello, S., García, G., Mariano-Jelicich, R., Ravasi, T., and Seco Pon, J. P. (2016). "Aves marinas de las costas bonaerenses," in La Costa Atlántica de Buenos Aires: Naturaleza y Patrimonio Cultural, eds C. Celsi and J. Athor (Buenos Aires: Fundación de Historia Natural Félix de Azara), 368-384.

Falabella, V., Campagna, C., and Croxall, J. P. (2009). Atlas del Mar Patagónico. Especies y espacios. Buenos Aires: Wildlife Conservation Society and BirdLife International.

Ferreira, J. M., Oliveira, L. R., Wynen, L., Bester, M. N., Guinet, C., MoraesBarros, N., et al. (2008). Multiple origins of vagrant Subantarctic fur seals: a long journey to the Brazilian coast detected by molecular markers. Polar Biol. 31, 303-308.

Finger, A., Lavers, J. L., Dann, P., Nugegoda, D., Orbell, J. D., Robertson, B., et al. (2015). The little penguin (Eudyptula minor) as an indicator of coastal trace metal pollution. Environ. Pollut. 205, 365-377. doi: 10.1016/j.envpol.2015. 06.022

Fossi, M. C., Pedà, C., Compa, M., Tsangaris, C., Alomar, C., Claro, F., et al. (2018). Bioindicators for monitoring marine litter ingestion and its impacts on Mediterranean biodiversity. Environ. Pollut. 237, 1023-1040.

Fossi, M. C., Baini, M., and Simmonds, M. P. (2020). Cetaceans as ocean health indicators of marine litter impact at global scale. Front. Environ. Sci. 8:255. doi: 10.3389/fenvs.2020.586627

Franco-Trecu, V., Aurioles-Gamboa, D., and Inchausti, P. (2014). Individual trophic specialisation and niche segregation explain the contrasting population trends of two sympatric otariids. Mar. Biol. 161, 609-618. doi: 10.1007/s00227013-2363-9

Franco-Trecu, V., Drago, M., Katz, H., Machín, E., and Marín, Y. (2017). With the noose around the neck: marine debris entangling otariid species. Environ. Pollut. 220, 985-989. doi: 10.1016/j.envpol.2016.11.057

FREPLATA (2021). Tratado del Río de la Plata y su Frente Marítimo. Available online at: http://ctmfm.org/sitio/documentos-basicos/tratado-rio-de-la-platafrente-maritimo/ (accessed February 20, 2021)

Franco-Trecu, V., Drago, M., Baladán, C., García-Olazábal, M. D., Crespo, E. A., Cardona, L., et al. (2015). Postharvesting population dynamics of the South American sea lion (Otaria byronia) in the southwestern Atlantic. Mar. Mamm. Sci. 31, 963-978.

Furness, R. W., and Camphuysen, K. (1997). Seabirds as monitors of the marine environment. ICES. J. Mar. Sci. 54, 726-737.

Gariboldi, M. C., Túnez, J. I., Dejean, C. B., Failla, M., Vitullo, A. D., Negri, M. F., et al. (2015). Population genetics of Franciscana Dolphins (Pontoporia blainvillei): introducing a new population from the southern edge of their distribution. PLoS One 10:e0132854. doi: 10.1371/journal.pone.0132854

Gandini, P., Boersma, P. D., Frere, E., Gandini, M., Holik, T., and Lichtschein, V. (1994). Magellanic Penguins (Spheniscus magellanicus) affected by chronic petroleum pollution along coast of Chubut, Argentina. Auk 111, 20-27. doi: $10.2307 / 4088501$

García-Borboroglu, P., Boersma, P. D., Ruoppolo, V., Pinho-Da-Silva-Filho, R., Corrado-Adornes, A., Conte-Sena, D., et al. (2010). Magellanic penguin mortality in 2008 along the SW Atlantic coast. Mar. Pollut. Bull. 60, 1652-1657. doi: 10.1016/j.marpolbul.2010.07.006

García-Borboroglu, P., Boersma, P. D., Ruoppolo, V., Reyes, L., Rebstock, G. A., Griot, K., et al. (2006). Chronic oil pollution harms Magellanic penguins in the
Southwest Atlantic. Mar. Pollut. Bull. 52, 193-198. doi: 10.1016/j.marpolbul. 2005.11.004

Giardino, G., Dellabianca, N. A., and García, N. A. (2019). "Globicephala melas" in Categorización 2019 de los Mamíferos de Argentina Según su Riesgo de Extinción. Lista Roja de los Mamíferos de Argentina. Available online at: http://cma.sarem. org.ar (accessed February 15, 2021).

Giardino, G., and García, N. A. (2019). "Kogia breviceps" in Categorización 2019 de los Mamíferos de Argentina según su riesgo de Extinción. Lista Roja de los Mamiferos de Argentina. Available online at: http://cma.sarem.org.ar (accessed February 15, 2021).

Geyer, R., Jambeck, J. R., and Law, K. L. (2017). Production, use, and fate of all plastics ever made. Sci. Adv. 3:e1700782. doi: 10.1126/sciadv.170 0782

González-Solís, J., Felicísimo, A., Fox, J. W., Afanasyev, V., Kolbeinsson, Y., and Muñoz, J. (2009). Influence of sea surface winds on shearwater migration detours. Mar. Ecol. Progr. Ser. 391, 221-230.

González Carman, V., Acha, E. M., Maxwell, S. M., Albareda, D., Campagna, C., and Mianzan, H. (2014a). Young green turtles, chelonia mydas, exposed to plastic in a frontal area of the SW Atlantic. Mar. Pollut. Bull. 78, 56-65. doi: 10.1016/j.marpolbul.2013.11.012

González Carman, V., Álvarez, K., Prosdocimi, L., Inchaurraga, M. C., Dellacasa, R. F., Faiella, A., et al. (2011). Argentinian coastal waters: a temperate habitat for three species of threatened sea turtles. Mar. Biol. Res. 7, 500-508. doi: $10.1080 / 17451000.2010 .528772$

González Carman, V., Botto, F., Gaitán, E., Albareda, D., Campagna, C., and Mianzan, H. (2014b). A jellyfish diet for the herbivorous green turtle Chelonia mydas in the temperate SW Atlantic. Mar. Biol. 161, 339-349. doi: 10.1007/ s00227-013-2339-9

González Carman, V., Bruno, I., Maxwell, S., Álvarez, K., Albareda, D., Acha, E. M., et al. (2016a). Habitat use, site fidelity and conservation opportunities for juvenile loggerhead sea turtles in the Río de la Plata. Argentina. Mar. Biol. 163:20. doi: 10.1007/s00227-015-2795-5

González Carman, V., Falabella, V., Maxwell, S., Albareda, D., Campagna, C., and Mianzan, H. (2012). Revisiting the ontogenetic shift paradigm: the case of juvenile green turtles in the SW Atlantic. J. Exp. Mar. Biol. Ecol. 429, 64-72. doi: 10.1016/j.jembe.2012.06.007

González Carman, V., Machain, N., and Campagna, C. (2015). Legal and institutional tools to mitigate plastic pollution affecting marine species: argentina as a case study. Mar. Pollut. Bull. 92, 125-133. doi: 10.1016/j. marpolbul.2014.12.047

González Carman, V., Mandiola, A., Alemany, D., Dassis, M., Seco Pon, J. P., Prosdocimi, L., et al. (2016b). Distribution of megafaunal species in the Southwestern Atlantic: key ecological areas and opportunities for marine conservation. ICES J. Mar. Sci. 73, 1579-1588. doi: 10.1093/icesjms/ fsw019

Guerrero, R., Acha, E., Framiñan, M. B., and Lasta, C. (1997). Physical oceanography of the Río de la Plata estuary, Argentina. Cont. Shelf Res. 17, 727-742. doi: 10.1016/S0278-4343(96)00061-1

Heaton, A. J., Pulis, E. E., Pitchford, J. L., Hatchett, W. L., Carron, A. M., and Solangi, M. (2016). Prevalence and transience of ingested fishing hooks in Kemp's ridley sea turtles. Chelonian Conserv. Bi. 15, 257-264. doi: 10.2744/ CCB- 1227.1

Hazen, E. L., Abrahms, B., Brodie, S., Carroll, G., Jacox, M. G., Savoca, M. S., et al. (2019). Marine top predators as climate and ecosystem sentinels. Front. Ecol. Environ. 17, 565-574.

Heink, U., and Kowarik, I. (2010). What are indicators? On the definition of indicators in ecology and environmental planning. Ecol. Indic. 10, 584-593. doi: 10.1016/j.ecolind.2009.09.009

Hilton, G. M., Furness, R. W., and Houston, D. C. (2000). A comparative study of digestion in North Atlantic seabirds. J. Avian Biol. 31, 36-46. doi: 10.1034/j. 1600-048X.2000.310106.x

Hilty, J., and Merenlender, A. (2000). Faunal indicator taxa selection for monitoring ecosystem health. Biol. Conserv. 92, 185-197. doi: 10.1016/S00063207(99)00052-X

Isacch, J. P., and Chiurla, E. H. (1997). Observaciones sobre aves pelágicas en el sudeste bonaerense, Argentina. Hornero 14, 253-254.

Jackson, S. (1992). Do seabird gut sizes and mean retention times reflect adaptation to diet and foraging method? Physiol. Zool. 65, 674-697. 
Jambeck, J. R., Geyer, R., Wilcox, C., Siegler, T. R., Perryman, M., Andrady, A., et al. (2018). Plastic waste inputs from land into the ocean. Science 347, $768-771$.

Jiménez, S., Abente, J. S., Azpiroz, A. B., Savigny, C., and Abreu, M. (2012). First Uruguayan records of Great-winged Petrel Pterodroma macroptera. BulletinBritish Ornithologists'. Club 132, 209-212.

Kühn, S., and van Franeker, J. A. (2020). Quantitative overview of marine debris ingested by marine megafauna. Mar. Pollut. Bull. 151:110858. doi: 10.1016/j. marpolbul.2019.110858

Kühn, S., Bravo Rebolledo, E. L., and van Franeker, J. A. (2015). "Deleterious effects of litter on marine life," in Marine Anthropogenic Litter, eds M. Bergmann, L. Gutow, and M. Klages (Cham: Springer International Publishing), 75-116.

Lebreton, L., and Andrady, A. (2019). Future scenarios of global plastic waste generation and disposal. Palgrave Commun. 5, 1-11. doi: 10.1057/s41599-0180212-7

Leite, A., Santos, L., Costa, Y., and Hatje, V. (2014). Influence of proximity to an urban center in the pattern of contamination by marine debris. Mar. Pollut. Bull. 81, 242-247. doi: 10.1016/j.marpolbul.2014.01.032

Lenzi, J., Burgues, M. A., Carrizo, D., Machín, E., and Teixeira-de Mello, F. (2016). Plastic ingestion by a generalist seabird on the coast of Uruguay. Mar. Pollut. Bull. 107, 71-76. doi: 10.1016/j.marpolbul.2016.04.016

López-Mendilaharsu, M., Estrades, A., Caraccio, M. N., Calvo, V., Hernández, M., and Quirici, V. (2006). "Biología, ecología y etología de las tortugas marinas en la zona costera uruguaya," in Bases Para la Conservación y el Manejo de la Costa Uruguaya, eds R. Menafra, L. Rodríguez-Gallego, F. Scarabino, and D. Conde (Montevideo: Vida Silvestre Uruguay), 247-257.

López-Mendilaharsu, M., Rocha, C. F. D., Miller, P., Domingo, A., and Prosdocimi, L. (2009). Insights on leatherback turtle movements and high use areas in the Southwest Atlantic Ocean. J. Exp. Mar. Biol. Ecol. 378, 31-39. doi: 10.1016/j. jembe.2009.07.010

Lozoya, J. P., Carranza, A., Lenzi, J., Machín, E., De Mello, F. T., González, S., et al. (2015). Management and research on plastic debris in Uruguayan aquatic systems: update and perspectives. Revista de Gestão Cost. Int. J. Int. Coast. Zone Manag. 15, 377-393. doi: 10.5894/rgci583

Lucas, A. J., Guerrero, R. A., Mianzan, H. W., Acha, E. M., and Lasta, C. A. (2005). Coastal oceanographic regimes of the Northern Argentine Continental Shelf (34-43으. Estuar. Coast. Shelf S. 65, 405-420. doi: 10.1016/j.ecss.2005.06.015

Machado, R., Wickert, J. C., Ott, P. H., and Nakashima, S. B. (2008). Tempo de passagem de alimento a través do trato digestório de Arctocephalus australis, estimado a partir de diferentes marcadores. Abstract retrieved from XIII Reunión de Trabajo de Especialistas en Mamíferos Acuáticos de América del Sur y $7^{\circ}$ Congreso SOLAMAC. 13 al 17 de octubre de 2008. Montevideo.

Mandiola, M. A. (2015). Evaluación de la presencia de lobos marinos de dos pelos Sudamericanos (Arctocephalus australis) en aguas de la provincia de Buenos Aires. [Ph. D, Thesis]. Universidad Nacional de Mar del Plata.

Marques, F. P., Cardoso, L. G., Haimovici, M., and Bugoni, L. (2018). Trophic ecology of Magellanic penguins (Spheniscus magellanicus) during the nonbreeding period. Estuar. Coast. Shelf Sci. 210, 109-122. doi: 10.1016/j.ecss.2018. 06.001

Martinez Souza, G. (2009). Ecologia alimentar da tartaruga marinha cabeçuda (Caretta caretta) no Oceano Atlântico Sul Ocidental, Uruguai. [Ph. D, Thesis]. Universidade Federal do Rio Grande.

Mianzan, H. W., Lasta, C., Acha, E., Guerrero, R., Macchi, G., and Bremec, C. (2001). The Rio de la Plata estuary, Argentina-Uruguay. Ecol. Stud. 144, 185-204. doi: 10.1007/978-3-662-04482-7_14

Miller, A., Nyberg, E., Danielsson, S., Faxneld, S., Haglund, P., and Bignert, A. (2014). Comparing temporal trends of organochlorines in guillemot eggs and Baltic herring: advantages and disadvantage for selecting sentinel species for environmental monitoring. Mar. Environ. Res. 100, 38-47. doi: 10.1016/j. marenvres.2014.02.007

Moore, E., Lyday, S., Roletto, J., Litle, K., Parrish, J. K., Nevins, H., et al. (2009). Entanglements of marine mammals and seabirds in central California and the north-west coast of the United States 2001-2005. Mar. Pollut. Bull. 58, 1045-1051. doi: 10.1016/j.marpolbul.2009.02.006

Moore, S. E. (2008). Marine mammals as ecosystem sentinels. J. Mammal. 89, 534-540. doi: 10.1644/07-MAMM-S-312R1.1
Mrosovsky, N., Ryan, G. D., and James, M. C. (2009). Leatherback turtles: The menace of plastic. Mar. Pollut. Bull. 58, 287-289. doi: 10.1016/j.marpolbul.2008. 10.018

Nelms, S., Duncan, E., Broderick, A., Galloway, T., Godfrey, M., Hamann, M., et al. (2016). Plastic and marine turtles: a review and call for research. ICES J. Mar. Sci. 73, 165-181. doi: 10.1093/icesjms/fsv165

Pacifici, M., Santini, L., Di Marco, M., Baisero, D., Francucci, L., Grottolo Marasini, G., et al. (2013). Generation length for mammals. Nat. Conserv. 5, 87-94. doi: 10.3897/natureconservation.5.5734

Pazos, R. S., Bauer, D. E., and Gómez, N. (2018). Microplastics integrating the coastal planktonic community in the inner zone of the Río de la Plata estuary (South America). Environ. Pollut. 243, 134-142. doi: 10.1016/j.envpol.2018. 08.064

Pazos, R. S., Maiztegui, T., Colautti, D. C., Paracampo, A. H., and Gómez, N. (2017). Microplastics in gut contents of coastal freshwater fish from Río de la Plata estuary. Mar. Pollut. Bull. 122, 85-90. doi: 10.1016/j.marpolbul.2017.06.007

Petry, M. V., and Benemann, V. R. (2017). Ingestion of marine debris by the whitechinned petrel (Procellaria aequinoctialis): is it increasing over time off southern Brazil? Mar. Pollut. Bull. 117, 131-135.

Pinto, M. B., Siciliano, S., and Di Beneditto, A. P. M. (2007). Stomach contents of the Magellanic penguin Spheniscus magellanicus from the northern distribution limit on the Atlantic coast of Brazil. Mar. Ornithol. 35, 77-78.

Piola, A. R., Romero, S. I., and Zajaczkovski, U. (2008). Space-time variability of the plata plume inferred from ocean color. Cont. Shelf Res. 28, 1556-1567. doi: 10.1016/j.csr.2007.02.013

Pitman, R. L., and Brownell, R. L. Jr. (2020). Mesoplodon densirostris. The IUCN Red List of Threatened Species 2020: e.T13244A50364253. Available online at: https://www.iucnredlist.org/species/13244/50364253 (accessed February 15, 2021).

Prosdocimi, L., Bugoni, L., Albareda, D., and Remis, M. I. (2015). Are stocks of immature loggerhead sea turtles always mixed? J. Exp. Mar. Biol. Ecol. 466, 85-91. doi: 10.1016/j.jembe.2015.02.006

Prosdocimi, L., Dutton, P. H., Albareda, D., and Remis, M. I. (2014a). Origin and genetic diversity of leatherbacks (Dermochelys coriacea) at argentine foraging grounds. J. Exp. Mar. Biol. Ecol. 458, 13-19. doi: 10.1016/j.jembe.2014.04.025

Prosdocimi, L., Bruno, I., Diaz, L., González Carman, V., Albareda, D., and Remis, M. (2014b). Southernmost reports of the hawksbill sea turtle, Eretmochelys imbricata (Linnaeus, 1766), in Argentina and evidence of a hybrid origin supported by mitochondrial DNA analysis. Herpetol. Rev. 45, 1-5.

Prosdocimi, L., González Carman, V., Albareda, D. A., and Remis, M. I. (2012). Genetic composition of green turtle feeding grounds in coastal waters of argentina based on mitochondrial DNA. J. Exp. Mar. Biol. Ecol. 412, 37-45. doi: 10.1016/j.jembe.2011.10.015

Provencher, J. F., Bond, A. L., Avery-Gomm, S., Borrelle, S. B., Bravo Rebolledo, E. L., Hammer, S., et al. (2017). Quantifying ingested debris in marine megafauna: a review and recommendations for standardization. Anal. Methods 9, 1454-1469. doi: 10.1039/C6AY02419J

Reisser, J., Slat, B., Noble, K., du Plessis, K., Epp, M., Proietti, M., et al. (2014). The vertical distribution of buoyant plastics at sea. Biogeosci. Dis. 11, 16207-16226. doi: 10.5194/bg-12-1249-2015

Rodríguez, D., and Bastida, R. (1998). Four hundred years in the history of pinniped colonies around Mar del Plata, argentina. Aquat. Conserv. Mar. Freshw. Ecosyst. 8, 721-735.

Rodríguez, D. H., Dassis, M., Ponce De León, A., Barreiro, C., Farenga, M., Bastida, R. O., et al. (2013). Foraging strategies of southern sea lion females in the La Plata River Estuary (Argentina-Uruguay). Deep Sea Res. Pt. II 88, 120-130. doi: 10.1016/j.dsr2.2012.07.012

Roman, L., Schuyler, Q. A., Hardesty, B. D., and Townsend, K. A. (2016). Anthropogenic debris ingestion by avifauna in eastern Australia. PLoS One 11:8. doi: 10.1371/journal.pone.0158343

Roman, L., Bell, E., Wilcox, C., Hardesty, B. D., and Hindell, M. (2019a). Ecological drivers of marine debris ingestion in Procellariiform seabirds. Sci. Rep. 9:916. doi: 10.1038/s41598-018-37324-w

Roman, L., Hardesty, B. D., Hindell, M. A., and Wilcox, C. (2019b). A quantitative analysis linking seabird mortality and marine debris ingestion. Sci. Rep. 9:3202. doi: 10.1038/s41598-018-36585-9

Romero, M. A., Grandi, M. F., Túnez, J. I., Gribaudo, C. A., Reyes, L.-M., Dassis, M., et al. (2019). “Otaria flavescens" in Categorización 2019 de los Mamíferos 
de Argentina Según su Riesgo de Extinción. Lista Roja de los Mamíferos de Argentina. Available online at: http://cma.sarem.org.ar (accessed February 15, 2021).

Ryan, P. G. (1987). The incidence and characteristics of plastic particles ingested by seabirds. Mar. Environ. Res. 23, 175-206. doi: 10.1016/0141-1136(87)90028-6

Ryan, P. G. (2015). How quickly do albatrosses and petrels digest plastic particles? Environ. Pollut. 207, 438-440. doi: 10.1016/j.envpol.2015.08.005

Ryan, P. G. (2018). Entanglement of birds in plastics and other synthetic materials. Mar. Pollut. Bull. 135, 159-164. doi: 10.1016/j.marpolbul.2018.06.057

Santos, R. G., Martins, A. S., Farias, J. D. N., Horta, P. A., Pinheiro, H. T., Torezani, E., et al. (2011). Coastal habitat degradation and green sea turtle diets in Southeastern Brazil. Mar. Pollut. Bull. 62, 1297-1302. doi: 10.1016/j.marpolbul. 2011.03.004

Schuyler, Q., Hardesty, B. D., Wilcox, C., and Townsend, K. (2014). Global analysis of anthropogenic debris ingestion by sea turtles. Conserv. Biol. 28, 129-139. doi: $10.1111 /$ cobi.12126

Schuyler, Q. A., Wilcox, C., Townsend, K., Hardesty, B. D., and Marshall, N. J. (2014). Mistaken identity? Visual similarities of marine debris to natural prey items of sea turtles. BMC Ecol. 14:14. doi: 10.1186/1472-6785-14-14

Schuyler, Q., Hardesty, B. D., Wilcox, C., and Townsend, K. (2012). To eat or not to eat? Debris selectivity by marine turtles. PLoS One 7:e40884. doi: 10.1371/ journal.pone.0040884

Secchi, E., Santos, M. C., de, O., and Reeves, R. (2018). Sotalia guianensis (Errata Version Published in 2019). The IUCN Red List of Threatened Species 2018, e.T181359A144232542. Available online at: https://dx.doi.org/10.2305/IUCN. UK.2018-2.RLTS.T181359A144232542.en (accessed February 15, 2021).

Sergio, F., Caro, T., Brown, D., Clucas, B., Hunter, J., Ketchum, J., et al. (2008). Top predators as conservation tools: ecological rationale, assumptions, and efficacy. Annu. Rev. Ecol. Evol. S. 39, 1-19. doi: 10.1146/annurev.ecolsys.39. 110707.173545

Siddig, A. A., Ellison, A. M., Ochs, A., Villar-Leeman, C., and Lau, M. K. (2016). How do ecologists select and use indicator species to monitor ecological change? Insights from 14 years of publication in ecological indicators. Ecol. Indic. 60, 223-230. doi: 10.1016/j.ecolind.2015.06.036

Silva Rodríguez, M. P., Favero, M., Berón, M. P., Mariano-Jelicich, R., and Mauco, L. (2005). Ecología y conservación de aves marinas que utilizan el litoral bonaerense como área de invernada. Hornero 20, 111-130.

Spalding, M. D., Fox, H. E., Allen, G. R., Davidson, N., Ferdaña, Z. A., Finlayson, M., et al. (2007). Marine ecoregions of the world: a bioregionalization of coastal and shelf areas. BioScience 57, 573-583. doi: 10.1641/B570707

Stokes, D. L., Boersma, P. D., and Davis, L. S. (1998). Satellite tracking of Magellanic Penguin migration. Condor 100, 376-381. doi: 10.2307/1370280

Stokes, D. L., Boersma, P. D., López de Casenave, J., and García-Borboroglu, P. (2014). Conservation of migratory Magellanic penguins requires marine zoning. Biol. Conserv. 170, 151-161. doi: 10.1016/j.biocon.2013.12.024

Tavares, D. C., de Moura, J. F., Merico, A., and Siciliano, S. (2017). Incidence of marine debris in seabirds feeding at different water depths. Mar. Pollut. Bull. 119, 68-73. doi: 10.1016/j.marpolbul.2017.04.012

Tiwari, M., Wallace, B. P., and Girondot, M. (2013). Dermochelys coriacea (Southwest Atlantic Ocean subpopulation). The IUCN Red List of Threatened Species 2013: e.T46967838A46967842. Available online at: https://dx.doi.org/10. 2305/IUCN.UK.2013-2.RLTS.T46967838A46967842.en (accessed February 20, 2021).

Tourinho, P. S., Ivar Do Sul, J. A., and Fillmann, G. (2010). Is marine debris ingestion still a problem for the coastal marine biota of southern Brazil? Mar. Pollut. Bull. 60, 396-401. doi: 10.1016/j.marpolbul.2009.10.013

Valente, A. L., Marco, I., Parga, M. L., Lavin, S., Alegre, F., and Cuenca, R. (2008). Ingesta passage and gastric emptying times in loggerhead sea turtles (Caretta caretta). Res. Vet. Sci. 84, 132-139. doi: 10.1016/j.rvsc.2007.03.013

Vales, D. G., Mandiola, A., Romero, M. A., Svendsen, G., Túnez, J. I., Negrete, J., et al. (2019). "Arctocephalus australis" in Categorización 2019 de los Mamíferos de Argentina Según su Riesgo de Extinción. Lista Roja de los mamíferos de Argentina. Available online at: http://cma.sarem.org.ar (accessed February 15, 2021).

van Franeker, J. A., and Law, K. L. (2015). Seabirds, gyres and global trends in plastic pollution. Environ. Pollut. 203, 89-96. doi: 10.1016/j.envpol.2015.02.034 van Franeker, J. A., Blaize, C., Danielsen, J., Fairclough, K., Gollan, J., Guse, N., et al. (2011). Monitoring plastic ingestion by the northern fulmar Fulmarus glacialis in the North Sea. Environ. Pollut. 159, 2609-2615. doi: 10.1016/j.envpol.2011. 06.008

Vaz Ferreira, R. (1982). Arctocephalus australis zimmerman, South American fur seal. Mammals in the Seas. FAO Fish. Series 4, 497-508.

Vélez-Rubio, G. M., Cardona, L., López-Mendilaharsu, M., Martínez Souza, G., Carranza, A., González-Paredes, D., et al. (2016). Ontogenetic dietary changes of green turtles (Chelonia mydas) in the temperate southwestern Atlantic. Mar. Biol. 163, 1-16. doi: 10.1007/s00227-016-2827-9

Vélez-Rubio, G. M., Estrades, A., Fallabrino, A., and Tomás, J. (2013). Marine turtle threats in Uruguayan waters: insights from 12 years of stranding data. Mar. Biol. 160, 1-15. doi: 10.1007/s00227-013-2272-y

Vélez-Rubio, G., Teryda, N., Asaroff, P., Estrades, A., Rodriguez, D., and Tomás, J. (2018). Differential impact of marine debris ingestion during ontogenetic dietary shift of green turtles in Uruguayan waters. Mar. Pollut. Bull. 127, 603-611. doi: 10.1016/j.marpolbul.2017. 12.053

Vermeulen, E., Failla, M., Loizaga, de Castro, R., Romero, M. A., Svendsen, G., et al. (2019). "Tursiops truncatus" in Categorización 2019 de los Mamíferos de Argentina Según su Riesgo de Extinción. Lista Roja de los Mamíferos de Argentina. Available online at http://cma.sarem.org.ar (accessed February 15, 2021.)

Wells, R. S., Rhinehart, H. L., Hansen, L. J., Sweeney, J. C., Townsend, F. I., Stone, R., et al. (2004). Bottlenose dolphins as marine ecosystem sentinels: developing a health monitoring system. EcoHealth 1, 246-254. doi: 10.1007/s10393-0040094-6

Wilcox, C., Van Sebille, E., and Hardesty, B. D. (2015). Threat of plastic pollution to seabirds is global, pervasive, and increasing. Proc. Natl. Acad. Sci. U.S.A. 112, 11899-11904. doi: 10.1073/pnas.1502108112

Yamasaki, F., Takahashi, K., and Kamiya, T. (1974). Digestive tract of la Plata dolphin, Pontoporia blainvillei I. Oesophagus and Stomach. Okajimas Folia Anatomica Japon. 51, 29-51. doi: 10.2535/ofaj1936. 51.1_29

Yorio, P., Marinao, C., Kasinsky, T., Ibarra, C., and Suárez, N. (2020). Patterns of plastic ingestion in Kelp Gull (Larus dominicanus) populations breeding in northern Patagonia, Argentina. Mar. Pollut. Bull. 156:111240. doi: 10.1016/j. marpolbul.2020.111240

Zacharias, M. A., and Roff, J. C. (2001). Use of focal species in marine conservation and management: a review and critique. Aquatic Conserv Mar. Freshw. Ecosyst. 11, 59-76. doi: 10.1002/aqc.429

Zerbini, A. N., Secchi, E., Crespo, E., Danilewicz, D., and Reeves, R. (2017). Pontoporia blainvillei (errata version published in 2018). The IUCN Red List of Threatened Species 2017: e.T17978A123792204. Available online at: https: //dx.doi.org/10.2305/IUCN.UK.2017-3.RLTS.T17978A50371075.en (accessed February 20, 2021).

Conflict of Interest: The authors declare that the research was conducted in the absence of any commercial or financial relationships that could be construed as a potential conflict of interest.

Publisher's Note: All claims expressed in this article are solely those of the authors and do not necessarily represent those of their affiliated organizations, or those of the publisher, the editors and the reviewers. Any product that may be evaluated in this article, or claim that may be made by its manufacturer, is not guaranteed or endorsed by the publisher.

Copyright (c) 2021 González Carman, Denuncio, Vassallo, Berón, Álvarez and Rodriguez-Heredia. This is an open-access article distributed under the terms of the Creative Commons Attribution License (CC BY). The use, distribution or reproduction in other forums is permitted, provided the original author(s) and the copyright owner(s) are credited and that the original publication in this journal is cited, in accordance with accepted academic practice. No use, distribution or reproduction is permitted which does not comply with these terms. 